Universidad de Lima

Facultad de Comunicación

Carrera de Comunicación

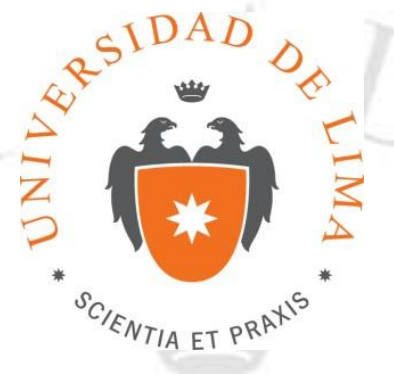

\title{
PROCESO DE REVOCATORIA A SUSANA VILLARÁN DE LA PUENTE: EL DEBATE EN LA "EXPOSICIÓN DE MOTIVOS"
}

Trabajo de investigación para optar el Título Profesional de Licenciado en Comunicación

\section{Alvaro Alonso Canales Caballero}

Código 20100205

\section{Asesora}

Lilian Kanashiro Nakahodo

\author{
Lima - Perú
}

Mayo de 2017 


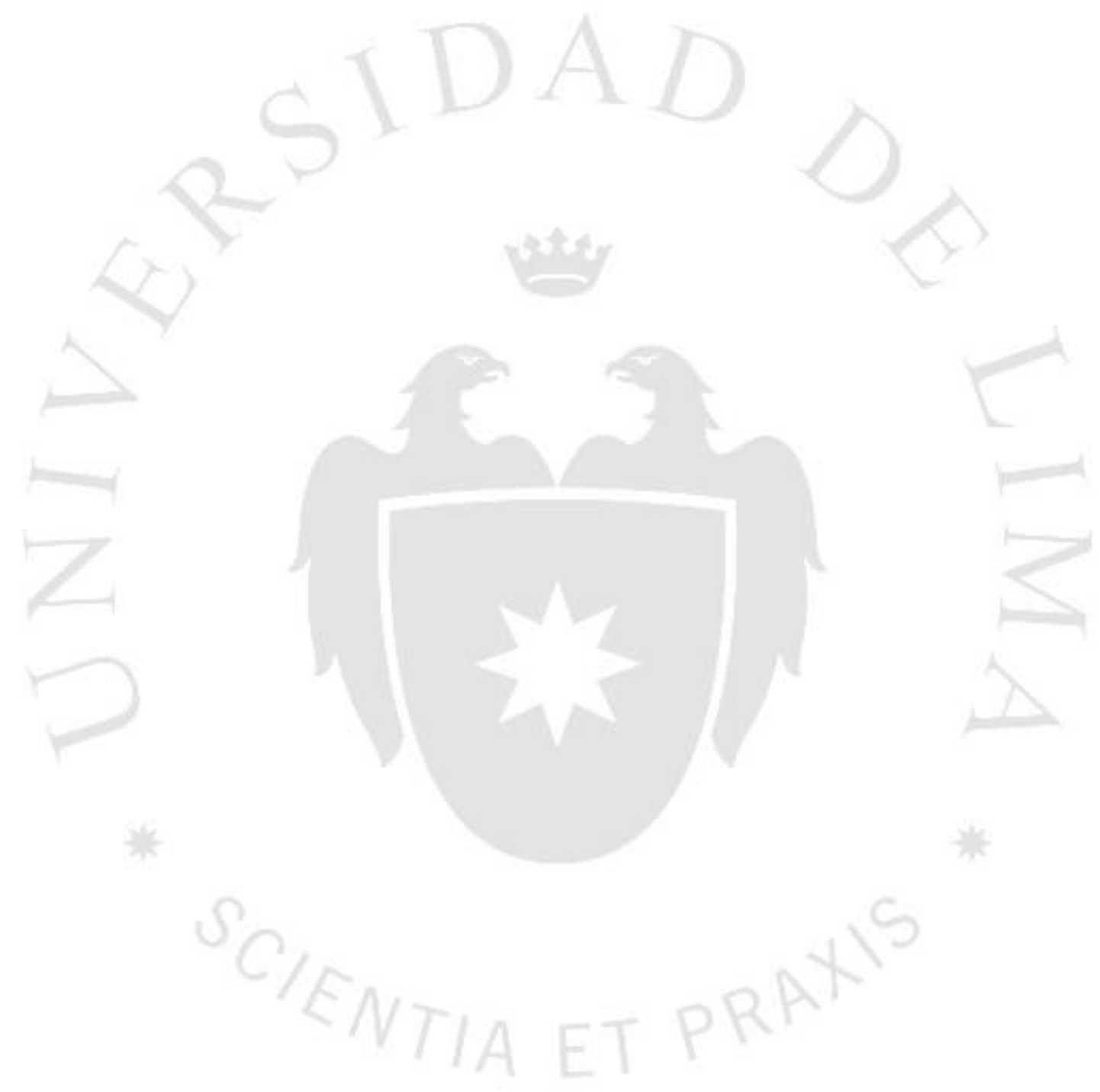




\section{PROCESO DE REVOCATORIA A SUSANA VILLARÁN DE LA PUENTE: EL DEBATE EN LA "EXPOSICIÓN DE MOTIVOS"}




\section{RESUMEN}

Con motivo del proceso de revocatoria a la exalcaldesa de Lima Susana Villarán De La Puente del año 2013, el presente artículo pretende determinar el papel que cumplen los debates televisados en el marco de una revocatoria; a razón de ello, se postula como objetivos específicos el análisis de las estrategias discursivas, la clasificación de la orientación temática y el estudio del lenguaje audiovisual. Para el desarrollo de los dos primeros objetivos se emplea la teoría de Téllez, Muñiz y Ramírez (2010) y, para el tercer objetivo, lo expuesto por Quintas y Quintas (2010). La metodología consiste, primero, en transcribir todo el evento, luego dividir lo obtenido en 76 segmentos y finalmente realizar un análisis cuantitativo de contenido. Los resultados hallados de lo anterior, arrojan que la estrategia discursiva más utilizada es el ataque, que la mayoría de las intervenciones tienen una orientación temática hacia la política y que se usa planos medios completamente rígidos para el encuadre de los participantes. Estos resultados permiten afirmar que los debates televisados, en el marco de una revocatoria, cumplen el papel de una "Exposición de motivos" (tal y como es denominado el evento durante el proceso mismo).

Palabras clave: exposición de motivos, fragmentación partidaria, volatilidad electoral, debates televisados, revocatoria.

\section{ABSTRACT}

On the occasion of the revocation process to the former mayor of Lima Susana Villaran De La Puente of 2013, the present article tries to determinate the paper of televised debates during the frame of a recall; for this reason, the analysis of discursive strategies, the classification of thematic orientation and the study of audiovisual language are postulated as specific objectives. For the development of the first two objectives, the theory of Téllez, Muñiz and Ramírez (2010) was used and, for the third objective, Quintas y Quintas (2010). The methodology consisted in first transcribing the whole event, then dividing the collected into 76 segments and finally performing a quantitative content analysis. The results obtained from the above, showed that the most used discursive strategy was the attack, that most of the interventions had a thematic orientation towards the politic and that were used average plans completely rigid for 
the framing of the participants. These findings allow affirming that televised debates, in the frame of a recall, play the role of an Exposition of Motives (as the event was called during the process itself).

Key words: exposition of motives, partisan fragmentation, electoral volatility, televised debates, revocation.

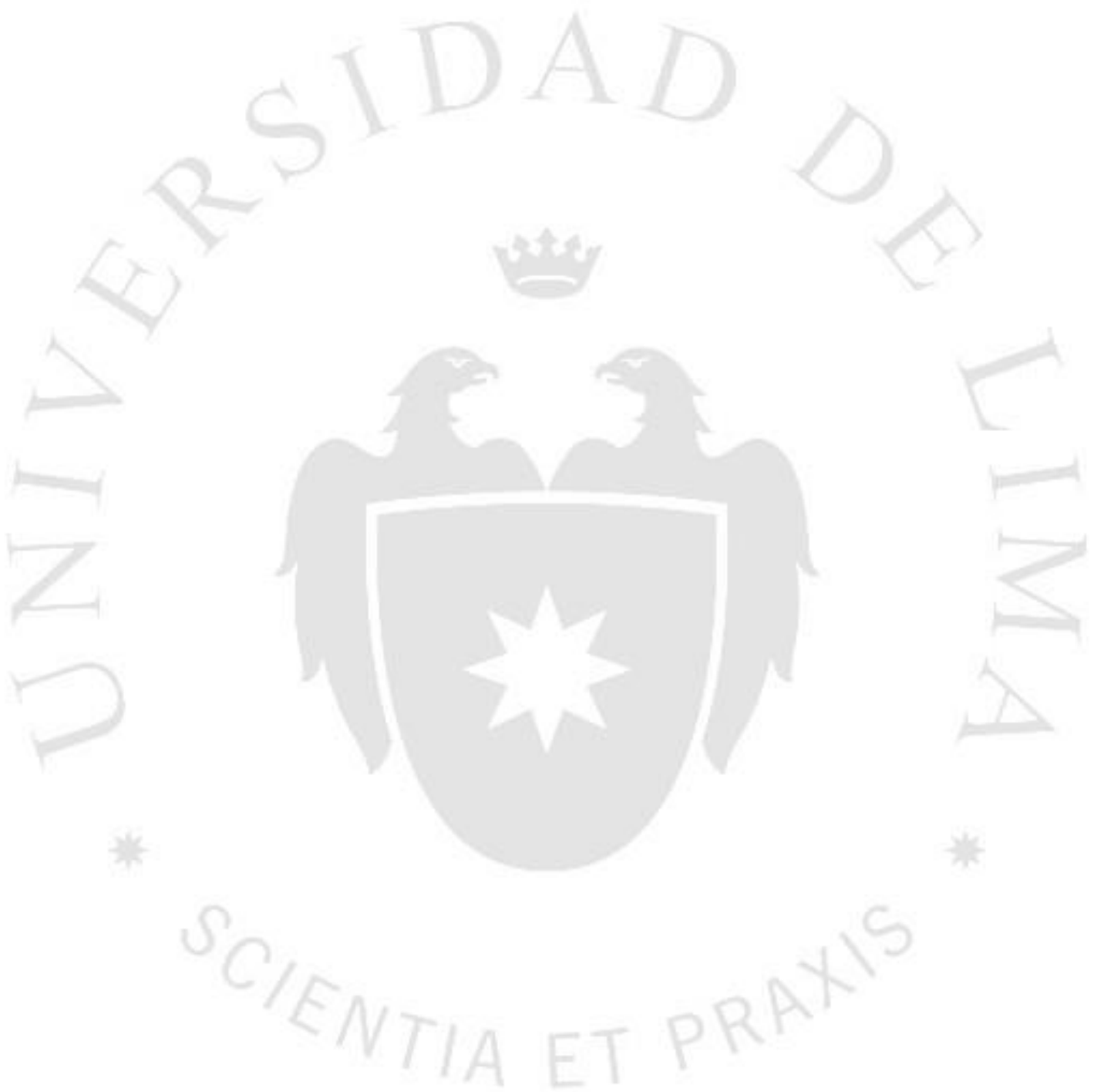




\section{ÍNDICE}

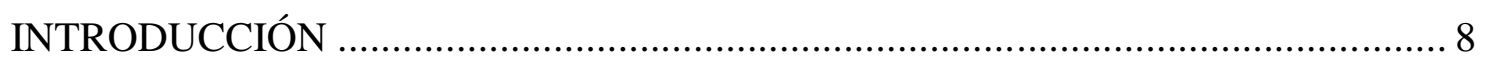

FRAGMENTACIÓN PARTIDARIA Y VOLATILIDAD ELECTORAL .................... 9

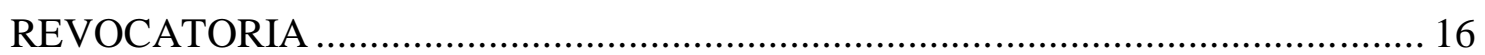

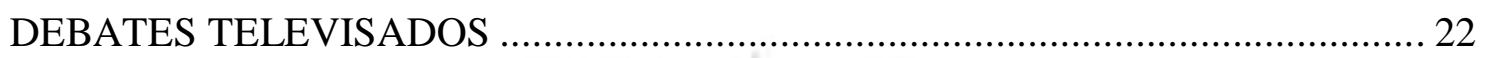

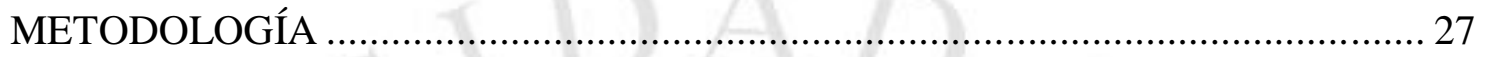

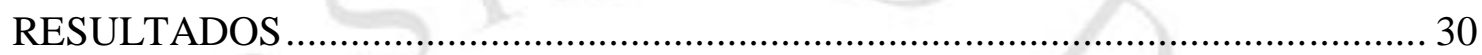

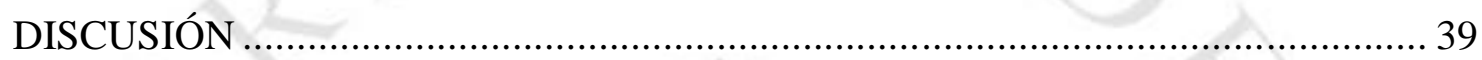

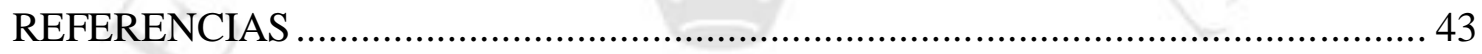




\section{ÍNDICE DE ANEXOS}

ANEXO 1: Libro de códigos 


\section{INTRODUCCIÓN}

Los debates televisados son mecanismos democráticos que se desarrollan en tiempos electorales, permitiendo al candidato transmitir sus propuestas y persuadir al elector para que le otorgue su voto. Un debate tradicional, tal y como explican distintos autores conocedores del tema, le ofrece al elector la posibilidad de conocer al candidato que pretende ocupar un cargo en la gestión pública, teniendo un alcance general y de primera mano de los lineamientos de su plan de gobierno, así como también un mejor conocimiento de su perfil político. En los debates tradicionales, que se dan cuando se pretende elegir a una autoridad, se lleva a cabo una deliberación de ideas entre los participantes. En algunos otros casos, como en las revocatorias de autoridades, este concepto del debate tradicional se altera y, en vez del intercambio natural de ideas, se da lugar a confrontaciones directas entre los participantes, ya que lo que se pretende es remover o mantener a una autoridad en su cargo. Lo que conlleva a plantear la pregunta de investigación: ¿qué papel cumple el debate en el marco de una revocatoria?

La "Exposición de motivos", como fue llamado por el Jurado Nacional de Elecciones (JNE), del 10 de marzo de 2013, entre las agrupaciones del "Sî" y del "No" a la revocatoria de la alcaldesa de Lima Susana Villarán De La Puente, dejó aspectos relevantes a investigar que van desde el discurso de cada uno de los participantes hasta el lenguaje audiovisual. Para tratar estos temas que se suscitaron en dicho evento, se plantea como objetivos específicos el análisis de las estrategias discursivas de los participantes, la clasificación de la orientación temática de cada intervención y el estudio del lenguaje audiovisual durante la transmisión. El primer objetivo, permite conocer la motivación y finalidad de cada discurso; es decir, si está dentro de los parámetros de lo que se puede catalogar como aclamación, ataque, defensa o concordancia. El segundo consiste en clasificar la orientación temática del discurso, la cual pudo haberse enfocado hacia la autoridad o hacia la política. El tercer y último objetivo, busca señalar si las tomas facilitaron la comunicación no verbal entre participante y audiencia. 


\section{FRAGMENTACIÓN PARTIDARIA Y VOLATILIDAD}

\section{ELECTORAL}

Durante los años setenta, las dictaduras militares y los golpes de Estado se habían vuelto acontecimientos nada extraños en el panorama político y electoral del Perú, así como de gran parte de los países de Latinoamérica (Silva, 2002, párr. 19). Algunos partidos políticos emergentes, como el Partido Popular Cristiano (PPC) o Acción Popular (AP), empiezan a ganar partidarios y a posicionarse como una alternativa seria y moderna a los regímenes militares —el Apra y algunas agrupaciones sociales y sindicales ya lo venían siendo desde varias décadas atrás (Silva, 2002, párr.

$1)$.

Tanaka señala, respecto de la férrea oposición a las disposiciones militares, que:

Los distintos gremios empresariales actuaron cada uno en defensa de sus intereses sectoriales durante el gobierno militar. Sin embargo, con los años, y coincidiendo con la transición democrática, creció entre los empresarios la conciencia de que era necesario actuar de manera concertada en defensa de la propiedad privada en general y de intereses más amplios (Tanaka, 1998, p. 77).

Estos tres partidos (Apra, PPC y AP) reflejaron las necesidades y voluntades de distintas partes del pueblo peruano, totalmente en contra de las dictaduras militares (Pásara, 1988, p. 153). Muchos ciudadanos se identificaron con lo que proponían sus respectivos líderes y fundadores a la vez (como Víctor Raúl Haya De La Torre, Luis Bedoya Reyes o Fernando Belaúnde Terry). No obstante, los dictadores de turno siempre vieron a los partidos políticos como una amenaza a sus propios intereses; su rápida expansión y aceptación en la sociedad hizo que los persiguieran y trataran de desacreditar frente a la opinión pública y, aunque en varios momentos de la década del setenta estuvieron cerca de lograrlo (con Juan Velasco Alvarado a la cabeza entre 1968 y 1975), los partidos políticos se fueron asentando como una fuerza ideológica e influyente (Tuesta, 1995, p. 37). Velasco, buscando distanciarse con los partidos, optó por conseguir el apoyo popular a través de reformas y obras, pero solo logró acentuar una oposición notable en la población. La transición definitiva de los regímenes 
militares a las democracias electorales se consolidó a partir de dos hechos claves: con la Asamblea Constituyente, en 1978, y con las elecciones presidenciales, en 1980 (Pásara, 1988, p. 152).

La década del ochenta trajo la consolidación (parcial) de los partidos políticos, de las elecciones transparentes y de los gobiernos democráticos. Fernando Belaúnde (AP) primero y luego Alan García (Apra) llegaron a ser gobierno siguiendo una ley orgánica partidaria; es decir, siendo primero elegidos representantes de sus partidos en asambleas generales o convenciones y luego participando en campañas electorales representando a sus respectivas agrupaciones políticas. Así, los partidos alcanzaron su máximo nivel de representación (Tanaka, 1998, p. 85).

Degregori, con referencia a las elecciones presidenciales de 1980, atribuye que:

Las primeras elecciones presidenciales posteriores a la caída del régimen militar ofrecían indicios de nuevas definiciones y realineamientos. Ellos parecían apuntar a la formación de un sistema de partidos competitivo con perspectivas de larga duración y posibilidades de reemplazos ordenados en el ejercicio del poder (Degregori, 1991, p. 24).

La capacidad de convocatoria de los partidos políticos y la gran aceptación de sus líderes facilitó la atención de las demandas de la sociedad criolla; sin embargo, se descuidó a los sectores populares y a la clase social emergente que provenía de las migraciones del campo a la ciudad. Esto, sumado a la irrupción del terrorismo y a las inadecuadas políticas económicas adoptadas, contribuyó a generar cierto desgaste y descontento en sectores de la población poco favorecidos que no se sintieron parte de las reformas que los partidos tradicionales planteaban (hecho que facilitaría la aparición y rápido crecimiento en las encuestas del outsider Fujimori en las elecciones de 1990).

El funcionamiento del sistema de partidos políticos inició la década de los años ochenta con una importante estabilización institucional forjada alrededor de los distintos frentes políticos y renovando el interés de los ciudadanos por participar en elecciones democráticas (Pásara, 1988, p. 151); a pesar de ello, este sistema cerró este periodo dejando muchas dudas y generando desconfianza entre los distintos estamentos sociales que, con distintos niveles de intensidad, habían sentido el impacto negativo de 
la poca visión macroeconómica de Belaúnde y de la hiperinflación causada por García en su intento fallido de estatizar la banca (Silva, 2002, párr. 4).

La década del noventa supuso el debilitamiento progresivo y la casi extinción de los partidos políticos tradicionales en el Perú. Esta situación se originó cuando un desconocido Alberto Fujimori resultó, contra todo pronóstico, vencedor de las elecciones presidenciales de 1990 superando a las agrupaciones políticas más representativas del país hasta ese momento y a candidatos de larga trayectoria en distintos ámbitos (político, literario, económico); lo que propició un cambio en el panorama político-electoral y un llamado de atención para los antiguos políticos. Los sectores populares y parte de la clase media mostraron su descontento con los partidos y sus modelos clasistas debido, principalmente, a que ya no se sentían representados ni atendidos por ellos. La masa social emprendedora encontró en Fujimori la posibilidad de ser parte del sistema y gozar de las condiciones que los partidos que fueron gobierno en la década anterior les negaron por distintas razones. El outsider Fujimori fue el único candidato que le ofreció a los sectores populares la alternativa real de desprenderse de la tutela de la clase política tradicional y, así, igualar condiciones económicas y de ciudadanía con los sectores medios de la capital (Degregori, 1991, p. 41).

Respecto de la victoria de Fujimori sobre Vargas Llosa en 1990, Tuesta precisa que:

Las preferencias de apristas a izquierdistas, que habían luchado duramente contra las propuestas neoliberales de Vargas Llosa, inclinaron el triunfo a favor de Fujimori en la segunda vuelta electoral, quien ofreció contraponer un programa distinto al duro y castigador que anunciaba el afamado novelista. Sin una organización partidaria, sin pasado político y con pocos recursos, el candidato Fujimori dio la sorpresa, en tanto los partidos políticos grandes sufrían una pérdida antes impensada de preferencias electorales (Tuesta, 1995, p. 43).

La llegada de Fujimori a la presidencia originó el colapso definitivo de los partidos políticos, dado que sus líderes perdieron credibilidad y los partidos dejaron de ser representativos a medida que las reformas económicas y sociales del Ejecutivo, contrario a lo que muchos estudiosos de la materia vislumbraban, alcanzaron relativo éxito a corto plazo y sin tanta retórica. Además, el mismo Fujimori se encargó de 
desprestigiar al sistema de partidos por su carácter obstruccionista e ineficiente (a su parecer) para generar gobernabilidad en todos los rincones del país. Y es con las elecciones presidenciales de 1995 que termina de colapsar el sistema de partidos políticos tradicionales, ya que ninguno alcanzó el 5\% de la votación, perdiendo así sus inscripciones ante el Jurado Nacional de Elecciones (Tanaka, 1998, p. 229).

Dargent sostiene que: "Mientras avanzaba la década, el fujimorismo justificó ampliar los nuevos programas sociales hacia zonas pobres urbanas" (2012, p. 133). La fortaleza de Fujimori radicaba en la opinión pública, con el apoyo de los sectores populares y teniendo controlados y medianamente satisfechos los intereses de los grupos económicos más fuertes, los partidos políticos no disponían de un amplio margen de acción para presentarse como una férrea oposición al fujimorismo. A raíz de esto, la oposición encuentra dificultades para la fiscalización, la rendición de cuentas y regulación de las actividades gubernamentales, lo que genera que la participación ciudadana sea cada vez menos viable (Fowks, 2015, p. 53).

Acerca del funcionamiento de los partidos políticos hacia el final de la década del noventa, Tanaka señala: “[...] el régimen político durante el fujimorismo se caracterizó por una lógica de apertura: ella fue parte de una estrategia para debilitar a los partidos tradicionales, fragmentar el campo opositor, dar lugar a organizaciones independientes y antipartidarias [...]" (Tanaka, 2005, p.104). Los partidos quedaron abandonados por sus grandes líderes de antaño, perdieron partidarios, se apartaron de la ideología bajo la que se fundaron, los militantes que quedaron se enfrentaron entre ellos por el control del partido en cuestión, entre otros. De esta manera, la fragmentación partidaria se había consumado de manera prácticamente irreversible.

En el marco político, el decenio del gobierno fujimorista no solo se caracterizó por el total debilitamiento de los partidos políticos o por los indicios de actos de corrupción y delitos de lesa humanidad, sino también por el modelo autoritario que implementó Fujimori en cada una de sus medidas. Sin llegar a ser una dictadura estrictamente, el gobierno llegó a corromper y a utilizar a su conveniencia a las distintas instituciones estatales — tales como las Fuerzas Armadas o el Poder Judicial- para mantenerse en el gobierno y facilitar la ejecución de sus medidas. Esta forma de gobernar se conoce como "autoritarismo competitivo" y es en donde existe un proceso democrático electoral, pero la oposición es incapaz de competir en igualdad de 
condiciones por el avasallante poder de quien maneja las instituciones estatales (Levitsky \& Loxton, 2013, p. 108).

Tanaka, refiriéndose al fin del gobierno de Fujimori, también asegura que:

Se debe caracterizar al fujimorismo dentro de la categoría de autoritarismos competitivos; esto es, se trató de un régimen democrático en lo formal, pero que funcionó con una lógica autoritaria, debido a que en el escenario político este se ubicó como actor claramente hegemónico, con un importante respaldo popular y social en general, y capaz de competir y ganar elecciones (Tanaka, 2005, p. 20).

A inicios del nuevo milenio, se hizo pública la primera prueba fehaciente de corrupción en el régimen fujimorista (sobre el video en donde aparece el exasesor Vladimiro Montesinos sobornando al excongresista Alberto Kouri), lo que supuso el fin del gobierno. Fujimori, recientemente electo en elecciones cuestionadas por la oposición, ante las primeras pruebas de corrupción y delitos de lesa humanidad en su contra, optó por renunciar vía fax desde Japón (país que le brindó asilo político y en donde no rige la extradición).

Sobre el fin de la era Fujimori, Tuesta agrega, en relación a la situación de los partidos, que:

Es recién con la caída del fujimorismo, que se retomó la necesidad de discutir y promulgar una ley de partidos políticos, norma que por cierto estuvo precedido por un número grande de iniciativas, las cuales nunca llegaron a prosperar. Existía, en realidad, una desconfianza alta hacia el Estado y sobre todo a que cualquier gobierno pudiera ingresar a manipular la vida de los partidos políticos, en un país de escasa tradición democrática (Tuesta, 2005, p.

94).

Con el estado de transición de Valentín Paniagua y los gobiernos siguientes, el panorama del sistema de partidos políticos no ha variado en gran medida, a pesar de las múltiples reformas impulsadas tanto por el Ejecutivo como por el Legislativo. El pueblo sigue percibiendo una gran desconfianza con respecto a los partidos, no hay representatividad ni identificación. Las agrupaciones políticas se han vuelto frágiles, mediatizadas y limeñizadas; aparecen de pronto para la contienda electoral del momento y terminan desapareciendo con la misma velocidad con la que se formaron 
(Degregori \& Meléndez, 2007, p. 135). Es así como surge la figura del "mal menor", como en las últimas cuatro elecciones presidenciales (2001, 2006, 2011 y 2016). Está táctica recurrente de votar por el mal menor en política consiste en elegir, entre todos los malos candidatos, al menos malo. Leonardo Amaya y Gloria Berrío-Acosta encuentran que en la figura del mal menor: "Es válida la elección de la opción que genera daño en un entorno en el cual no es posible garantizar la beneficencia y se está obligado a actuar. De este modo se reconoce la opción con mal menor como el mayor bien posible" (2015, párr. 1).

Siguiendo con su aporte acerca de la crisis partidaria, Tanaka argumenta que:

En general, se ha llamado la atención sobre una serie de problemas en los partidos: caudillismo, falta de democracia interna, falta de renovación, falta de preparación y calificación de sus líderes y cuadros, lógicas cortoplacistas, proliferación de actos de corrupción en sus militantes, falta de contacto con la ciudadanía y con la sociedad civil, etc., los cuales son defectos presentes en mayor o menor medida en todos los partidos (Tanaka, 2005, p. 98).

En estos dieciséis años de alternancia democrática e institucionalidad del Estado, los partidos siguen ajenos a la modernización y sus formas ideológicas parecen obsoletas para atraer simpatizantes. El elector no le da su voto a quien mejor argumenta, está más preparado o cuenta con el mejor equipo, sino al que le cae bien, al que le parece bonito, al que le da risa, etc., y no le toma mucho tiempo decidir su voto: lo hace en el momento cercano o el mismo día de la votación. Es así como se origina la volatilidad electoral.

Este concepto tiene que ver con el comportamiento cambiante e imprevisto del elector a puertas de unas elecciones (Tanaka, 2005, p. 103). Los ciudadanos, al no sentirse representados ni identificados con algún partido político, son más susceptibles de dejarse convencer por algún personaje desconocido y su discurso fugaz. En los últimos años y cada vez con mayor frecuencia, el voto en el Perú es inconsistente, el elector cambia su elección de un momento a otro y por cuestiones muchas veces intranscendentes como algún gesto, alguna omisión o provocación, alguna postura determinada con respecto a un tema coyuntural, etc. El nivel de volatilidad electoral ha ido aumentando, mientras que el grado de identificación con los partidos políticos ha 
ido disminuyendo, generando mayor impacto sobre los ciudadanos indecisos (Luengo, 2011, p. 93).

Tuesta también explica, sobre la injerencia de la volatilidad electoral, que: Siendo los procesos electorales presidenciales los más importantes, las inclinaciones ciudadanas se han centrado de manera preferencial en la figura del líder, en desmedro del propio partido. Esto ha permitido la volatilidad del electorado peruano (Tuesta, 1995, p. 87).

Por lo expuesto anteriormente, se entiende que la fragmentación partidaria consumada en la década del noventa, ocasionó lo que se ha denominado como "volatilidad electoral". Este concepto es muy importante para continuar con la investigación, ya que explica (en buena parte) por qué y cómo se originó la motivación de revocar a la alcaldesa de Lima Susana Villarán. Al carecer de una cultura política respaldada por partidos institucionalizados, el elector es susceptible a ser fácilmente persuadido. En el contexto del proceso revocatorio, la "Exposición de motivos", resulta determinante para captar la intencionalidad del voto dado el comportamiento y el pensamiento tan inestable del ciudadano común. 


\section{REVOCATORIA}

Por primera vez en su historia, el Perú atraviesa una fase de gobiernos elegidos democráticamente. La democracia de hoy en día ha ido evolucionando y ya no se habla tanto de regímenes de izquierda o de derecha, pero sí de modelos económicos. En el caso peruano, se sigue un modelo económico liberal que mezcla los fundamentos del capitalismo con las disposiciones del libre mercado bajo una mirada, si vale el término, moderna y de centro. Esta nueva democracia, con sus pros y sus contras, trata de abrir nuevos horizontes para el desarrollo, la inclusión y la descentralización, por citar algunos ejemplos.

El Perú atraviesa una etapa democrática que se conoce como "democracia plebiscitaria". El sitio web del Diccionario de la Lengua Española explica que el plebiscito consiste en una consulta que los poderes públicos someten al voto popular directo para que apruebe o rechace una determinada propuesta sobre una cuestión política o legal. Concepto que se diferencia con el de democracia representativa o directa, debido a que antepone la voluntad de la ciudadanía ante lo constitucional.

Esta democracia plebiscitaria, promovida por el gobierno de Fujimori a su voluntad, atenta contra la democracia representativa y contribuye al debilitamiento de los partidos políticos. Sobre este aspecto, Domínguez señala que, en modelos autoritarios, "los gobernantes ejecutan los comunicación política de manera unidireccional y, los gobernados, la practican de forma oculta y reservada" (2014, p. 9). Por ello, se genera inestabilidad en la medida en que se empodera al ciudadano de a pie en las decisiones de interés público, como lo son las elecciones democráticas o las revocatorias (Montoya, 2012, p. 150). El rol de la ciudadanía se ha convertido en un activo y ha cobrado una importancia enorme en el ámbito electoral, volviéndose un factor decisivo para el accionar político.

Sin embargo, a pesar de este renaciente espíritu democrático en la sociedad peruana, existen mecanismos que de alguna manera debilitan la democracia. En 2013, Lima experimentó un proceso que otorga a los ciudadanos la facultad de suspender a una autoridad de sus funciones de acuerdo a la ley vigente. La remoción o revocación de autoridades, así como la demanda de rendición de cuentas, son derechos políticos que pueden asumir los ciudadanos mediante referéndum, facultad que los limeños 
asumieron para el intento de revocatoria de Villarán (Constitución Política del Perú, 1993, artículo $31^{1}$ ).

En los estados democráticos y con un sistema de gobierno presidencialista, esto supone que todo ciudadano tenga la oportunidad de participar en una contienda electoral (sea como parte del electorado o como candidato y de manera individual o asociada). Es un derecho fundamental de toda persona el ser parte activa del desarrollo político, económico, social y cultural del país. A su vez, con el derecho de la libre elección también se tiene el derecho a la revocatoria, gracias a postulaciones constitucionales y de referéndum (plebiscitos).

La revocatoria, en términos generales, es un proceso democrático en donde los electores, así como eligieron libremente a su autoridad principal (en este caso a Susana Villarán, alcaldesa de Lima), también tienen la capacidad y el derecho (cuestionable o no) de relevar a dicha autoridad de su cargo, sin que primen argumentos de justicia. Si la mayoría está de acuerdo, entonces se procede a la intervención; el deseo de la mayoría manda, tal y como lo avala la democracia directa (al ser un mecanismo de la misma) y figura en la Constitución de 1993, aunque sin sonados precedentes.

En la Constitución de 1979, se explica el funcionamiento de la revocatoria y en qué circunstancias es válida; además, se hace referencia al derecho de los ciudadanos a participar en los asuntos públicos (Constitución Política del Perú, 1979, artículo 64²). Sin embargo, es en la Constitución de 1993 donde se amplía el alcance de la revocatoria apareciendo en dos artículos, siendo los casos para los que aplica para: alcaldes (distritales y provinciales) y presidentes, vicepresidentes y consejeros regionales (Constitución Política del Perú, 1993, artículos 191 y 194).

Montoya expone los pasos para que la revocatoria se realice:

<http://www.leyes.congreso.gob.pe/Documentos/constituciones_ordenado/CONSTIT_1993/Texto_actual izado_CONS_1993.pdf>. EXTO_CORREGIDO.pdf>. 
Preparación del presupuesto de los organismos electorales, elaboración y aprobación del padrón electoral respectivo, constitución e instalación de Jurados Electorales Espaciales y de Oficinas Descentralizadas de Procesos Electorales, establecimiento de mesas de sufragio, así como designación y capacitación oportuna de sus miembros, diseño, impresión y distribución del material electoral a utilizarse y, además, su aprobación para afrontar el proceso de consulta popular, entre otras actividades (Montoya, 2012, p. 83).

Para llevar a cabo una revocatoria en el Perú (país de Sudamérica con mayor número de intentos de revocatoria) es necesario, previa compra del kit electoral y recolección de firmas de adhesión por parte de los promotores de la revocatoria, llamar a una consulta popular dentro del espacio gubernamental de la autoridad que se desea revocar de sus funciones. Además, la revocatoria solo procede durante el segundo y el tercer año de gobierno de las autoridades regionales y municipales. Asimismo, para que el proceso se lleve a cabo es necesario que al menos el 50\% de los ciudadanos del padrón electoral hayan emitido su voto (Montoya, 2012, p. 97).

En este punto, uno de los cuestionamientos que se dan desde un inicio es el de conocer cuáles son realmente los verdaderos intereses de estos promotores. Hay quienes promueven la revocatoria impulsados por intereses personales o de grupos de poder. Dejando de lado las motivaciones reales, aquellas que se basan en valores y principios morales, respetables y honestos (Montoya, 2012, p. 157). El punto es que las verdaderas intenciones de los promotores no se llegan a saber a ciencia cierta hasta después de la consulta popular, por lo que su credibilidad es siempre cuestionable.

Pero este proceso de revocatoria no rige para todas las autoridades gubernamentales; es decir, no es aplicable para los miembros de alguno de los tres poderes del Estado: Ejecutivo, Legislativo y Judicial. A pesar que el presidente y los congresistas son elegidos por el pueblo, la revocatoria es única y exclusivamente para las autoridades municipales. Esta disposición genera algunas contradicciones; ya que, suponiendo que la revocatoria sea un mecanismo legítimo en una democracia directa, entonces también debería ser factible revocar a un mandatario o a un parlamentario si es la voluntad de la mayoría. Si fuera así, muchos tendrían que dejar sus cargos por el gran descontento del pueblo, generándose un desequilibrio en la gobernabilidad del país. 
La cuestión radica en que, para el caso de las elecciones de autoridades regionales y municipales, gana el candidato que haya obtenido más votos en una primera y única vuelta. Así sea por un solo voto, es válido y se reconoce el triunfo de manera legítima y democrática. En este tipo de elecciones predomina el principio de "mayoría simple" (gana el que saca más votos entre todos), en lugar del de "mayoría absoluta" (gana el que tiene más de la mitad de votos), el cual se da en elecciones presidenciales (Manent, 2014, párr. 1).

En este contexto, vale la pena mencionar que Susana Villarán ganó las elecciones municipales con un $38,39 \%$ frente a un $37,56 \%$ por parte de Lourdes Flores o, lo que es lo mismo, con una diferencia de 38022 votos. En dicha elección, se presentaron nueve candidatos. El ser electa alcaldesa de Lima con esta mínima diferencia supuso que su Consejo Municipal este conformado por veintiún regidores de su propio partido y dieciocho de oposición (Tuesta, 2014, p. 76). Indudablemente, al ganar bajo la modalidad de mayoría simple, se evidenció que no era del agrado de un considerable número de limeños quienes, al conocer acerca del mecanismo de la revocatoria, no dudaron en apoyarlo.

Tuesta explica por qué la revocatoria se ha vuelto tan popular y goza de gran aceptación:

La revocatoria ha ganado adeptos debido a la creciente insatisfacción ciudadana con la gestión, algo que se refuerza en el nivel local. Buena parte de la población considera que los gobernantes no respetan ni sus promesas de campaña ni sus opiniones, y perciben que la corrupción ha calado profundamente en las instituciones. Así, la revocatoria permitiría ajustar cuentas (Tuesta, 2014, p. 29).

En el imaginario social, la percepción de Villarán se tornó negativa y se produjo una suerte de ensañamiento contra su figura que se replicó rápidamente en el colectivo popular, tildándola de poco capaz e ineficiente (Tuesta, 2014, p. 83). El intento de revocatoria difícilmente fue un hecho fortuito y aislado, tuvo que ser bien planificado $\mathrm{y}$, quienes promovían vacar a la alcaldesa, debieron tener fuertes motivaciones, conocimientos y presupuestos elevados acorde a la magnitud del suceso. Si había una voluntad política oculta para sacar a Villarán del cargo, uno de los 
primeros nombres que figuran es el del actual alcalde de Lima, Luis Castañeda Lossio. Y motivos suficientes tenía.

A finales de 2010, Castañeda renuncia a la alcaldía de Lima para participar en las elecciones presidenciales del año siguiente. Los sondeos de opinión de la época lo colocan en el primer puesto en la intención de voto, situación sumamente favorable de la que gozó por varias semanas (Ipsos Apoyo, 2010, p. 3). Sin embargo, cuando Villarán asume la alcaldía, casi inmediatamente y a falta de pocos meses para las elecciones presidenciales, dispone de una investigación completa a la gestión anterior. Temas como el de Comunicore, el Metropolitano o Cofopri empiezan a salir a la luz con bastante difusión y perjudicando la imagen de Castañeda. La intención de voto del burgomaestre decae considerablemente y, por último, debido a este y a otros factores conocidos, termina perdiendo las elecciones.

Aquella sensible situación pudo haber generado ánimos de venganza en Castañeda Lossio y, junto a la activa participación de Patricia Juárez (mano derecha del actual alcalde de Lima) como promotora del "Sî̀" a la revocatoria, son indicios lo suficientemente consistentes como para suponer que Solidaridad Nacional intentó la vacancia de Villarán.

Acerca del trasfondo real del proceso revocatorio a la alcaldesa, Tuesta sostiene que:

La revocatoria como institución de democracia directa está lejos de ser un mecanismo de control, utilizado de manera adecuada por los ciudadanos, como se mostró en el caso de Lima. Sirvió [por el contrario] para aglutinar fuerzas políticas que aprovecharon los problemas y errores de la gestión de la alcaldesa Susana Villarán para activar un proceso que produjo efectos negativos sobre un municipio que tuvo serios problemas para obtener en marcha políticas favorables para la ciudad (Tuesta, 2014, p. 92).

Entender en qué consiste la revocatoria, lo que implica a favor o en contra de la sociedad y el rol de los actores que participan en ella es esencial para luego contextualizar el evento central de análisis de esta investigación, que es el debate (denominado en esta coyuntura como "Exposición de motivos"). Con lo expuesto hasta el momento, se ha desarrollado el proceso histórico de la fragmentación partidaria que origina la volatilidad electoral; lo que a su vez explica la motivación real del intento de 
revocatoria a Villaran (quien obtuvo su cargo en elecciones democraticas), considerando Ia Hgil $e$ inestable conciencia politica de los peruanos. En el siguiente capitulo, se analiza el papel del debate televisado como proceso natural en epocas electorales y, asi, consolidar el cumplimiento de los objetivos planteados. 


\section{DEBATES TELEVISADOS}

Con el respaldo de los medios de comunicación, los líderes pueden llegar con mayor facilidad a la opinión pública e injerir positiva o negativamente, siempre y cuando estén capacitados y cuenten con las habilidades necesarias (Crespo, 2011, p. 12). Al mismo tiempo, la opinión pública ha tomado un protagonismo considerable en el debate de los políticos, haciendo que su voz sea escuchada. Las autoridades saben que los medios - sobre todo la televisión - son un gran aliado al momento de influir y persuadir al elector en épocas electorales, pero también puede ser un gran enemigo. Con la presión de las masas sociales, la televisión puede contribuir seriamente a destruir una imagen.

Tellería destaca la importancia de la televisión de la siguiente manera:

Hoy en día, la televisión construye la actualidad. Esto condena al silencio y a la indiferencia a los hechos huérfanos de imagen. Poco a poco se establece en las mentes la idea de que la importancia de los acontecimientos es proporcional a su riqueza visual. $\mathrm{O}$, por decirlo de otro modo, que un acontecimiento que se puede mostrar — si es posible en directo y en tiempo real- es más potente, más eminente, que el que permanece invisible (Tellería, 2007, p. 18).

Los debates televisados peruanos, influenciados por el modelo norteamericano, no siempre han mantenido un mismo formato. Desde el debate presidencial de 1990 entre Fujimori y Varga Llosa, se ha visto distintas maneras de desarrollar un evento de esta naturaleza. Los debates presidenciales posteriores al del noventa usualmente mantuvieron una tendencia argumentativa y confrontacional entre participantes.

Para asistir y ser parte de este acontecimiento democrático, los participantes (políticos, técnicos, ciudadanos destacados o ilustres desconocidos) se preparan con cierta anticipación y aprovechan su tiempo al aire para mencionar todo lo que se proponen decir y no necesariamente para comunicar lo que el público realmente exige y merece escuchar de un candidato que pretende llegar a gobernar. Los debates televisados se convierten, de esta manera, en fuentes informativas debido a su alto potencial para generar "comprensión bien informada", otorgándole mayor valor a los procesos democráticos (Echevarría \& Chong, 2013, p. 347). Siendo así que algunos 
políticos pueden sacar provecho de este tipo de situaciones para mejorar su imagen y expresar sus planes de gobierno.

Contreras resalta el cuidado a los detalles en televisión y valora el discurso del participante frente a cámaras de la siguiente manera:

Las tremendas audiencias que se aglutinan frente al monitor condicionan también la elaboración de cada detalle. Los errores serán públicos y notorios al menor fallo. Por último, el limitado acceso al medio, en especial en países como el nuestro donde, pese a la reciente aparición de los canales privados de televisión, la oferta de canales es limitada, multiplica el valor de cada segundo de presencia en pantalla (Contreras, 1990, p. 49).

Durante los debates televisados, la teleaudiencia o público electoral cumple un rol muy importante; ya que no solo recibe el mensaje de los candidatos, sino que también lo analiza, juzga, aprueba o desaprueba según su performance. Tuesta sintetiza sobre los medios que: "Es conocido que los medios de comunicación no solo son vehículos de expresión, sino también creadores de opinión pública" (Tuesta, 2005, p. 151). Dada la volatilidad electoral en el Perú, el más mínimo detalle puede ser decisivo para que el elector reafirme o cambie su voto. Hace muchos años que la teleaudiencia dejó de tener una función meramente pasiva y expectante, ahora tiene un posicionamiento relevante y una participación activa. El elector sabe perfectamente lo que ve y lo que escucha, así como lo que no.

La figura del debate televisado tradicional implica la participación de dos candidatos y un moderador; de esta manera, se asegura una repartición equilibrada de los tiempos de cada segmento según el tema. Desde que se empezaron a desarrollar los debates (empezando por el presidencial de 1990 del que se tiene registro, aunque no fue el primero en ser televisado), por lo general se ha mantenido una secuencia definida con cierta anticipación a la fecha del evento mismo.

No obstante, el modelo peruano (tan cambiante) no es excluyente en cuanto al número de participantes. Prueba de ello se da en las primeras vueltas para las elecciones presidenciales, en donde son invitados a participar todos los candidatos, los más representativos o los que ocupan las primeras posiciones. En otros casos - como por ejemplo los comicios de 2016-, los llamados a debatir no fueron los mismos candidatos a la presidencia, sino a la vicepresidencia. 
Asimismo, durante las últimas elecciones presidenciales, en lugar de un "todos contra todos" o de un "uno contra uno", se llevó a cabo un debate conformado por cinco duplas elegidas al azar, suceso que pone en evidencia la poca rigidez en el formato, sobre todo en las primeras vueltas, ya que cada organismo realiza la estructura del debate según sus parámetros. Al tener un mayor número de participantes, el evento puede desbordarse e impedir que se den intervenciones equitativas y lo suficientemente precisas como para persuadir al elector.

Por otro lado, la temática de los debates, así como su estructura (dividida en bloques previamente acordados durante las negociaciones) y forma, puede variar según el trasfondo del mismo. Un debate televisado que tiene a dos aspirantes para llegar a la presidencia o a la alcaldía suele tener similitudes en los aspectos mencionados. Pero un debate con un mayor número de participantes y otro objetivo, como el de revocar a una autoridad de sus funciones, difícilmente pueda abordar el tema económico, político y de seguridad de manera profunda (Kanashiro, 2015, p 46). Esto hace que el formato muchas veces sea repetitivo y no termine de abarcar todo los temas acordados y que el público espera.

El tiempo de duración de un debate en el Perú, normalmente, es de alrededor de dos horas; aunque este tiempo puede variar según cómo lo gestionen los participantes previamente al debate mismo y considerando el tiempo destinado a los comerciales. La duración de las intervenciones también es variable, ya que se considera un tiempo para la presentación y otro para la réplica, acorde a la cantidad de temas a desarrollar.

Respecto a la puesta en escena, que va desde el montaje hasta la presentación de los candidatos (en términos de apariencia), también influye en el desarrollo del programa y es que el debate televisado, en el fondo, no deja de ser un programa de televisión. Por ello, realizar un evento de esta naturaleza implica un gran despliegue audiovisual para que así la transmisión de la participación de cada candidato sea la adecuada y les sea favorable para sintonizar con la teleaudiencia (Kanashiro, 2015, p. 105). Actualmente, los debates ya no pueden ser catalogados como simples programas de televisión, por el contrario, se han convertido en espectáculos televisivos en donde la clase política ha asumido el manejo del lenguaje audiovisual (Pérez-Ruiz \& Melgosa, 2015, p. 130). 
Los estudios acerca de los debates televisados en los últimos años muestran tres tipos de tendencias sobre su implicancia con la ciudadanía en el marco de una contienda electoral: positiva, negativa y neutral.

Durante la década de los setenta, la televisión se convirtió en un medio muy importante para la sociedad peruana no solo por su carácter de entretenimiento, sino también por su carácter informativo, permitiendo que la audiencia, en tiempos electorales, disponga de un espacio para atender las promesas de quienes pretendían alcanzar un cargo de poder y construir su propia imagen del "candidato ideal". Luego del régimen de Fujimori (catalogado como un autoritarismo competitivo), las organizaciones electorales en el Perú revitalizaron la figura del debate al punto de calificarlo como "imprescindible" durante un periodo electoral y, más aún, en una democracia directa. Además, la importancia del debate radica en que se convierte no solo en una herramienta o mecanismo de la democracia, sino también de las comunicaciones masivas en épocas electorales y a favor del ciudadano (Fowks, 2015, p.

$50)$.

Por otro lado, pensadores como Sartori o Vargas Llosa ven un impacto un tanto negativo en torno a los debates. La formación de una opinión puede ser malintencionada, dejando de lado la parte constructiva y analizable que debe inferir naturalmente el elector, lo que se debe pretender es que la opinión pública sea espontánea (Sartori, 2003, p.53). Igualmente, algunos políticos agregan un sentimentalismo altruista a sus discursos durante el debate; sin embargo, difícilmente logran plasmarlos de llegar a ser gobierno. En la práctica, se deja de lado todas esas aseveraciones "bonitas" que se dicen en el debate debido al apetito voraz de poder y a la influencia de intereses particulares (Vargas Llosa, 2010, p. 102). En otras palabras, los debates no reflejan necesariamente lo que significaría la victoria de uno $\mathrm{u}$ otro candidato, pueden ser controversiales y llegar a confundir al elector.

Al mismo tiempo, comentadas las posturas a favor y en contra de los debates televisados, existe una mirada neutral acerca de los mismos y de sus efectos en el elector.

Los contenidos políticos en televisión pueden ser superficiales y estar alejados de la realidad, lo que no afectaría positiva ni negativamente a un candidato, generando mensajes efímeros. Por ejemplo, en relación al debate entre Vargas Llosa y Fujimori de 
1990, Salcedo sostiene que: "Las imágenes, las actitudes, la presencia del candidato, su puesta en escena, serían tanto o más importantes que los argumentos y los programas. El equipo de Vargas Llosa confiaba en que todo ello favorecería a su candidato" (1990, p. 96). En esta ocasión, la exhaustiva preparación que tuvo el aclamado escritor no le ayudó a consolidar su intención de voto y terminó perdiendo las elecciones; lo que demuestra la teoría de Salcedo, en cuanto a que una gran preparación no supone necesariamente salir vencedor. Por lo tanto, la importancia del debate no es tan significativa a la larga.

Se sostiene también que la postura de un candidato durante un debate no tiene mucha relevancia si no posee una estrategia de campaña definida y bien orientada. Y si, sobre todo, no cuenta con una organización política detrás que lo respalde; ya que el candidato debe ser un "interlocutor" entre su partido y el público; al no contar con una agrupación sólida y bien estructurada, su discurso carece de fundamento. Así, las consecuencias o el impacto del debate son mínimos.

Para sintetizar lo expuesto en este capítulo se puede decir que, si bien es cierto que los debates televisivos peruanos aún no se han institucionalizado completamente como mecanismo democrático, sí han logrado convertirse en una herramienta sumamente útil para los candidatos y se han posicionado de manera expectante para el elector. Su carácter persuasivo y argumentativo se vio reflejado en la "Exposición de motivos" de 2013 como parte del proceso de revocatoria a Villarán. 


\section{METODOLOGÍA}

Planas encuentra que en tiempos electorales:

La obligación de ejercer esta intermediación se hace mayor para la televisión, porque solo con un equitativo acceso de los candidatos y agrupaciones en pugna a espacios políticos apropiados en la TV -si es con debate mucho mejor- podrán favorecerse niveles de información mínimos para una decisión y definición más consciente y racional del voto ciudadano (Planas, 2001, p. 223).

Ese es y debe ser el objetivo de un debate: persuadir al elector para elegir a una autoridad. Afirmación que lleva a reflexionar y replantear si los debates en el Perú, en el marco de una revocatoria, pueden ser catalogados como tal; teniendo en su lugar, una "Exposición de motivos" en donde se prioriza la libertad plena de expresión al participante sobre la base de un guión, contribuyendo a la elaboración de la hipótesis general de esta investigación que plantea: "En el marco de una revocatoria, los debates televisados cumplen el papel de una exposición de motivos”.

Con respecto a la primera hipótesis, se recoge parte del estudio del investigador estadounidense William Benoit, quien concluyó en tres tipos de estrategias discursivas que pueden suscitarse en una contienda televisiva en tiempos electorales: ataque, aclamación y defensa. A partir de estos conceptos, más el de la concordancia que fue desarrollado en investigaciones posteriores a la de Benoit, se plantea que, en Estados Unidos y México, la estrategia que predomina es la de la aclamación seguida del ataque (Téllez, Muñiz \& Ramírez, 2010, p. 262). Por ello, tomando como referencia los hallazgos en estos dos países que practican un tipo de democracia directa y sistema presidencialista, se conforma la primera hipótesis de investigación: "La estrategia discursiva más usada durante el evento es la aclamación”.

En cuanto a la segunda hipótesis, esta también se sustenta en el estudio de Benoit sobre los debates norteamericanos. El autor encuentra que las intervenciones con orientación temática hacia la política se emplean en mayor medida que las que aluden a la autoridad. Además, hace uso del término "candidato", pero en la presente investigación se le denomina "autoridad", ya que Susana Villarán es —en el momento de la revocatoria - una autoridad (propiamente dicho) en funciones y no una aspirante a un puesto en la gestión pública. De igual forma, halla que los participantes que se 
dirigen a la política suelen vencer a quienes lo hacen a la autoridad (Téllez, Muñiz \& Ramírez, 2010, p. 257). Así, la segunda hipótesis de investigación queda articulada de la siguiente manera: "Las intervenciones con orientación temática hacia la política son las más utilizadas por los participantes".

Para la tercera hipótesis, se plantea la noción acerca de la sensación de cercanía entre expositor y telespectador sobre la base del estudio de Eva y Natalia Quintas (2010), del cual, se obtiene que "los planos cortos tienen la capacidad de introducirnos en la psicología del candidato y facilitarnos más detalles de su fisonomía" (Quintas \& Quintas, 2010, p.32). Conforme a lo señalado, se sostiene la tercera hipótesis de investigación: "Los planos empleados durante la transmisión del evento facilitan la comunicación no verbal".

Para llevar a cabo la investigación y poder cumplir con los objetivos planteados y comprobar las hipótesis señaladas, se hizo un análisis cuantitativo de contenido, a propósito de la "Exposición de motivos", para posteriormente realizar una sistematización de los resultados encontrados. Para ello, primero se transcribió todo el evento, teniendo en cuenta los tiempos y las intervenciones de cada uno de los expositores y del moderador. Una vez finalizada la transcripción, se seleccionaron setenta y seis segmentos de las intervenciones de los participantes de ambos grupos. Esta fragmentación se hizo de acuerdo al contenido de cada discurso y considerando si era una primera intervención o una réplica.

Como parte del proceso de investigación de la primera y la segunda hipótesis, se realizaron fichas de control (76), considerando a la agrupación, la estrategia, la orientación temática de la intervención, la duración, el participante y el segmento al que correspondía la intervención. Luego, se realizó la codificación respectiva (ver libro de códigos, anexo 1, p. 47). Adicionalmente, se complementó y validó el resultado con un estudio de fiabilidad estadística a partir de las estrategias discursivas y de la orientación temática de las intervenciones, considerando las frecuencias (absolutas y relativas), la media y la desviación estándar. Para ello, se empleó la fórmula Kappa (к) que permitió medir la concordancia de las variables por estrategia y orientación del discurso de manera general, por agrupación y por género.

Los indicadores con los que se trabajó para la validación de las dos primeras hipótesis fueron seis, los cuales consistieron en: agrupación (se refiere a qué agrupación 
corresponde la intervención, al "Sî́” o al "No"), estrategia (si es que el participante destinó su intervención para la aclamación de sus acciones o decisiones, para el ataque hacia el rival, para la defensa ante los ataques del contrario o para la concordancia en puntos en común, en caso los haya), orientación temática (se considera si la estrategia que usó el expositor está en función de la política y lo hecho durante la gestión o en función de la autoridad, que sería la propia Susana Villarán), tiempo (durante qué minutos fue la intervención), participante (describe quién fue el participante, ya sea entre Patricia Juárez, Eduardo Zegarra, Marisa Glave, Pablo Secada, Iván Becerra, Luis Castillo o Luis Calvimontes) y segmento (consiste en identificar cada uno de los setenta y seis segmentos registrados).

Por otro lado, el estudio del lenguaje audiovisual derivó en un análisis técnico, estimando el número de planos, la toma, el ángulo de la cámara, el encuadre y el número de intervenciones por expositor. Para profundizar en lo sucedido durante la transmisión y llevar un mejor control de los datos recogidos, también se elaboraron fichas de control (ocho) considerando al moderador y a cada uno de los siete participantes.

En esta parte, para la contrastación de la tercera hipótesis, los indicadores analizados fueron cinco: planos (se refiere a la cantidad de planos que se tiene por cada intervención), toma (consiste en identificar cómo es el plano de la persona en pantalla: plano medio para los participantes y plano general para la presentación y el cierre), ángulo (variación del ángulo de la cámara varía según la agrupación: de derecha a izquierda para el "Sî" y de izquierda a derecha para el "No"), encuadre (posición de la figura en la pantalla con respecto al eje del participante, eje lateral o central) e intervenciones (número de intervenciones de cada expositor). 


\section{RESULTADOS}

La transcripción de la "Exposición de motivos" facilitó la obtención de algunos datos relevantes para el posterior proceso de investigación. El evento contó con seis bloques expositivos para los participantes, cada uno sobre un tema en particular. En el primer bloque se respondió a la pregunta: “Debe dejar el cargo la alcaldesa?”; en el segundo, tercer y cuarto bloque se respondió a: “¿Debe dejar el cargo de regidor?”; y, por último, en los bloques quinto y sexto se dio un mensaje por parte de los regidores en contra de la revocatoria.

Al inicio de cada bloque, el primer participante contó con tres minutos y cincuenta segundos para su presentación y argumentación seguida de una intervención del rival de un minuto. Para el tercer bloque, no hubo ningún representante del "Sî", por lo que se tuvo que guardar silencio absoluto durante el turno de algunos de los promotores del 'Sî', cumpliendo el acuerdo previamente realizado por ambas partes. En un primer momento, se respetó todo el tiempo asignado, pero luego se otorgó un tiempo simbólico de treinta segundos. Además, el teniente alcalde de Lima, el regidor por Fuerza Social Eduardo Zegarra, fue el único de los participantes que dio el mensaje final dirigido al público en el último bloque del certamen electoral.

A continuación, se muestran y explican los resultados obtenidos mediante tablas con las respectivas frecuencias absolutas y relativas de las estrategias discursivas y de las orientaciones temáticas de las intervenciones de cada participante, durante el evento completo y por cada agrupación; asimismo, se indicará el grado de fiabilidad estadística de cada sección. Por último, se desarrolla lo que arrojó el estudio de la parte audiovisual.

\section{ESTRATEGIA DISCURSIVA MÁS UTILIZADA EN LA "EXPOSICIÓN DE MOTIVOS"}

La estrategia más utilizada durante el evento fue el ataque, mientras que la menos empleada fue la defensa; no hubo concordancia. La fiabilidad estadística, calculada con la fórmula Kappa ( $\kappa)$, dio como resultado 0,89 para las variables de las 
estrategias discursivas. Esto significa que el estudio de esta sección tiene un alto grado de fiabilidad.

Tabla 1

Estrategias discursivas durante la "Exposición de motivos"

\begin{tabular}{|c|c|c|}
\hline Estrategia discursiva & Frecuencia absoluta & Frecuencia relativa \\
\hline Ataque & 40 & 0,52 \\
\hline Aclamación & 21 & 0,28 \\
\hline Defensa & 15 & 0,20 \\
\hline Concordancia & 0 & 0 \\
\hline Total & $\mathbf{7 6}$ & $\mathbf{1}$ \\
\hline
\end{tabular}

Nota: las variables de ataque, aclamación, defensa y concordancia se obtuvieron de la división y posterior clasificación de cada uno de los setenta y seis segmentos. La frecuencia absoluta se calculó sumando el número de veces que se usaba una determinada estrategia, mientras que la frecuencia relativa se halló de la división de la frecuencia absoluta de una de las cuatro estrategias entre el total de todas.

El ataque entre los integrantes de las agrupaciones no fue tan enardecido, sin agravios ni tonos de voz elevados. Consistió sí en cuestionamientos y en increpaciones mutuas por la posición que habían adoptado y la forma de llevarla a cabo; por ejemplo: "A los regidores les corresponde fiscalizar y no por cercanía amical o ideológica se pueden poner de costado" (agrupación del "Sî"; ver transcripción en anexo 3, p. 62); “[...] esta herramienta política de revocación no obedece al genuino interés social, sino obedece a intereses políticos individuales" (agrupación del "NO"; ver transcripción en anexo 3, p. 59). Muchos de los ataques se realizaron en forma de pregunta: “¿Por qué prometió en campaña liderar la lucha contra la inseguridad ciudadana y no ha cumplido?" (agrupación del "Sî”; ver transcripción en anexo 3, p. 55); “[...] ¿por qué en dos años solo hizo 167 escaleras y tres muros de contención y no 1200 escaleras como nos mintió [...]" (agrupación del "Sî"; ver transcripción en anexo 3, p. 56). La mayoría de ataques fueron respondidos con otro ataque y, en menor cantidad, por una aclamación; por mencionar algunas réplicas: "Nuestra gestión ha potenciado lo bueno que encontramos y corregido sus errores pero, además, ha generado nuevos proyectos para el beneficio de todos" (agrupación del "No"; ver transcripción en anexo 3, p. 57); 
"La ambición del partido de la señora no quiere esperar a las elecciones del año 2014 y ahora le costará a Lima la friolera de 250 millones de soles el próximo domingo" (agrupación del "No"; ver transcripción en anexo 3, p. 59). Como se dejaba entrever previamente a la "Exposición de motivos" y considerando los antecedentes acerca de la existencia de esta estrategia en debates y acontecimientos pasados, la concordancia no fue una opción a tener en cuenta por los participantes.

\section{ESTRATEGIA DISCURSIVA DEL "Sí”}

La agrupación a favor del "Sî" centró su estrategia en torno al ataque. Los promotores de la revocatoria a Villarán fueron representados únicamente por Patricia Juárez, quien mantuvo el mismo tono confrontacional a lo largo de todo el evento. En este caso, la fiabilidad estadística (y por ende, la concordancia) fue total, ya que alcanzó la unidad (1).

Tabla 2

Estrategias discursivas del "Sí"

\begin{tabular}{|c|c|c|}
\hline Estrategia discursiva & Frecuencia absoluta & Frecuencia relativa \\
\hline Ataque & 26 & 0 \\
\hline Aclamación & 0 & 0 \\
\hline Defensa & 0 & 0 \\
\hline Concordancia & 0 & $\mathbf{1}$ \\
\hline Total & $\mathbf{2 6}$ & $\mathbf{2}$ \\
\hline
\end{tabular}

Nota: las variables estudiadas (estrategias discursivas) se obtuvieron de las intervenciones segmentadas (26) de la representante del "Sî".

Cada intervención de Juárez consistió en algún tipo de acusación, cuestionamiento u objeción contra la causa de sus contendores. Atacó la imagen de la alcaldesa y lo hecho durante su gestión, aunque también hizo alusión a los regidores y a su proceder durante los años en el Consejo Metropolitano de Lima. A continuación, algunas de sus intervenciones: “[...] más dinero nos viene costando la inoperancia e incapacidad en la gestión de la señora Villarán De la Puente" (ver transcripción en anexo 3, p. 59); “[...] ¿con qué criterio seleccionó a sus regidores metropolitanos, que 
demuestran ser personas poco conocedoras de temas municipales?” (ver transcripción en anexo 3, p. 61); “[...] el Municipio no es la señora Villarán y sus regidores. Ya se acabó el tiempo de los señores feudales o de los patrones de hacienda o capataces" (ver transcripción en anexo 3, p. 59).

\section{ESTRATEGIA DISCURSIVA DEL "NO"}

La coalición por el "No" empleó una estrategia más equitativa entre el ataque, la aclamación y la defensa. Como respuesta a los ataques del "Sí", el "No" centró su estrategia discursiva en la aclamación y también, aunque en menor medida, utilizó el ataque y la defensa (prácticamente con la misma frecuencia) para contrarrestar a la otra parte y tratar de convencer de su posición a la audiencia. Los regidores de la bancada de la alcaldesa fueron quienes mostraron mayor convicción en sus argumentos. El 0,84 de fiabilidad estadística también demuestra un elevado grado de concordancia como en los casos anteriores.

\begin{tabular}{|c|c|c|}
\hline \multicolumn{3}{|c|}{ Tabla 3 } \\
\hline Estrategias discursivas del NO \\
\hline Atrategia discursiva & Frecuencia absoluta & Frecuencia relativa \\
\hline Aclamación & 14 & 0,28 \\
\hline Defensa & 21 & 0,42 \\
\hline Concordancia & 15 & 0,30 \\
\hline Total & 0 & 0 \\
\hline
\end{tabular}

Nota: las variables estudiadas (estrategias discursivas) se obtuvieron de las intervenciones segmentadas (50) de los representantes del "No".

Como se mencionó anteriormente, las estrategias utilizadas por esta agrupación fueron muy variadas; a continuación algunos ejemplos en cuanto a la estrategia de ataque, aclamación y defensa respectivamente: “[...] esta herramienta política de revocación no obedece al genuino interés social, sino obedece a intereses políticos individuales" (ver transcripción en anexo 3, p. 69); "Hemos contribuido con la gestión en obras de infraestructura vial importantes [...]" (ver transcripción en anexo 3, p. 70); 
“[...] no debo ser revocado porque creo que he cumplido honestamente el encargo que la ciudad de Lima me dio cuando me eligió regidor [...]" (ver transcripción en anexo 3, p. 73).

\section{ORIENTACIÓN TEMÁTICA DE LAS INTERVENCIONES DE AMBAS AGRUPACIONES}

Por otro lado, las intervenciones con orientación política fueron las que predominaron durante la "Exposición de motivos". En términos generales, las intervenciones de los expositores consistieron en hacer alusión a la gestión municipal, ya sea como punto específico de la aclamación, del ataque o de la defensa. No obstante, las intervenciones con referencia a la autoridad también alcanzaron una cantidad considerable y fueron realizadas en su mayoría por los integrantes del "No" (tal y como se verá más adelante). Asimismo, la fiabilidad estadística calculada también con la fórmula Kappa ( $\kappa$ ) dio como resultado 0,89 para las variables temáticas (autoridad y política), lo que denota un alto grado de fiabilidad.

Tabla 4

Orientación temática de las intervenciones en la "Exposición de motivos"

\begin{tabular}{|c|c|c|}
\hline Tema & Frecuencia absoluta & Frecuencia relativa \\
\hline Autoridad & 30 & 0,39 \\
\hline Política & 46 & 0,61 \\
\hline Total & $\mathbf{7 6}$ & $\mathbf{1}$ \\
\hline
\end{tabular}

Nota: las variables de autoridad y política se obtuvieron de la división y posterior clasificación de cada uno de los setenta y seis segmentos. La frecuencia absoluta se calculó sumando el número de veces que se hacía referencia a una determinada temática, mientras que la frecuencia relativa se halló de la división de la frecuencia absoluta de una de las dos temáticas entre el total de todas.

\section{ORIENTACIÓN TEMÁTICA DE LAS INTERVENCIONES DEL "Sí”}

Los ataques del "Sí” fueron mayoritariamente orientados hacia la política. Como todos los grados de concordancia obtenidos previamente, el de este análisis 
también obtuvo una medición muy alta: el resultado de la fiabilidad estadística arrojó 0,91 .

Tabla 5

Orientación temática de las intervenciones del "Sí"

\begin{tabular}{|c|c|c|}
\hline Tema & Frecuencia absoluta & Frecuencia relativa \\
\hline Autoridad & 8 & 0,31 \\
\hline Política & 18 & 0,69 \\
\hline Total & $\mathbf{2 6}$ & $\mathbf{1}$ \\
\hline
\end{tabular}

Nota: las variables estudiadas (temas) se obtuvieron de las intervenciones segmentadas (26) de la representante del "Sî".

Los siguientes dos primeros ejemplos muestran una orientación temática hacia la política en el discurso de Patricia Juárez. Primero, alude a la construcción de una obra pública y luego a la gestión del manejo de los peajes en vías de Lima: “¿Por qué paralizó el túnel Santa Rosa por cuatro años [...]?” (ver transcripción en anexo 3, p. 56); “¿Por qué subirán los peajes, se crearán nuevos peajes y por qué se entregaron las vías de Lima a empresas brasileñas por 30 años por incapacidad de su gestión de hacer obra pública?" (ver transcripción en anexo 3, p. 57). En el siguiente ejemplo, sucede lo contrario, ya que Juárez dirige su discurso con el objetivo de atacar la imagen del regidor Eduardo Zegarra (siendo la orientación temática de la intervención hacia la autoridad): “¿Por qué permite que el señor Zegarra, quien es regidor tenga asignada una camioneta, cuando el uso de los bienes municipales les está prohibido a los regidores y eso señor Zegarra, podría constituir peculado de uso?” (ver transcripción en anexo 3, p. $61)$.

\section{ORIENTACIÓN TEMÁTICA DE LAS INTERVENCIONES DEL "NO”}

Por su parte, la agrupación del "No" equilibró más la orientación temática de sus intervenciones en función de la autoridad y de la política, aunque este último obtuvo una ligera ventaja. En esta ocasión, el grado de concordancia fue un poco menor que en el resto de análisis, pero igual de válido: se obtuvo 0,79 de fiabilidad estadística.

\section{Tabla 6}


Orientación temática de las intervenciones del "No"

\begin{tabular}{|c|c|c|}
\hline Tema & Frecuencia absoluta & Frecuencia relativa \\
\hline Autoridad & 22 & 0,44 \\
\hline Política & 28 & 0,56 \\
\hline Total & $\mathbf{5 0}$ & $\mathbf{1}$ \\
\hline
\end{tabular}

Nota: las variables estudiadas (temas) se obtuvieron de las intervenciones segmentadas (50) de los representantes del "No".

La regidora de Fuerza Social Marisa Glave alude en su discurso a la alcaldesa Villarán, lo que permite que su intervención sea clasificada como referente a la autoridad: "Susana Villarán ha trabajado de manera incansable" (ver transcripción en anexo 3, p. 62). La siguiente intervención fue por parte de Pablo Secada (regidor del PPC) y con orientación temática hacia la política, ya que menciona lo hecho durante su gestión: "El túnel se cayó y se está haciendo bien para que no se vuelva a caer cuando pasen por ahí los carros" (ver transcripción en anexo 3, p. 67).

Los expositores con más intervenciones fueron Patricia Juárez por el “'Sî̉ y Eduardo Zegarra por el "No". La primera fue la principal vocera Luis Castañeda y, junto a Marco Tulio Gutiérrez y algunas personalidades del Apra, una de las caras más visibles del "Sín”. Durante el proceso de revocatoria, apareció con bastante frecuencia en los medios de comunicación (sobre todo en televisión y diarios). Participó en los dos primeros bloques de la "Exposición de motivos", siendo la única por parte del grupo promotor del "Sî" e interviniendo hasta en ocho oportunidades. Mientras que Eduardo Zegarra, principal defensor de Susana Villarán, encabezó a la agrupación por el "No" junto a Marisa Glave y tuvo seis intervenciones, dos más que la propia Marisa Glave y que Iván Becerra, regidor por el partido político Restauración Nacional.

\section{RESULTADOS DEL ESTUDIO DEL LENGUAJE AUDIOVISUAL}

Para las intervenciones de los siete participantes se empleó el plano medio, manteniendo la imagen cercana del individuo desde el torso hasta la cabeza, sacando de encuadre los demás elementos que están alrededor de la figura central y manteniendo la atención únicamente en la persona dentro del plano. 
En todo momento, el encuadre que se mantuvo partió del eje central. La cámara que grababa a los expositores permaneció inmóvil permanentemente y mantuvo a los personajes al medio del cuadrado de la pantalla, permitiendo un enfoque directo y frontal durante toda la transmisión, sin paneos.

\section{Figura 1}

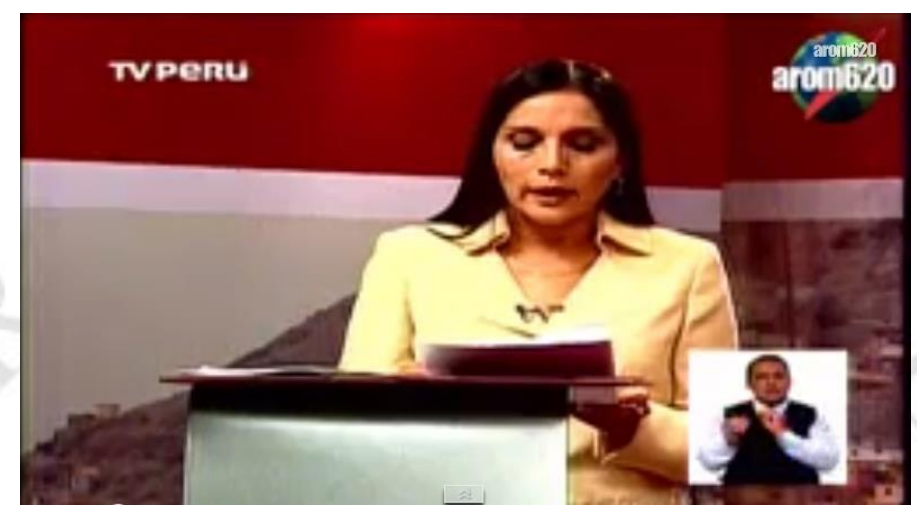

\section{Intervención de Patricia Juárez}

Nota: en la imagen se aprecia el plano medio y el encuadre centrado durante la participación de unos de los expositores.

Además, salvo para la participación de Patricia Juárez que fue de derecha a izquierda, el ángulo de la cámara para la participación de los miembros del "No" inició de izquierda a derecha y así permaneció hasta los cortes comerciales, en donde el ángulo fue frontal. Los expositores del "No", en sus respectivos turnos, intercalaron la dirección de sus miradas entre la cámara y su contendora. Patricia Juárez constantemente se dirigía a la cámara, hablándole directamente al público. Vale precisar que todos los participantes hicieron lectura de apuntes durante sus discursos. No hubo movilidad ni dinamismo en el juego de cámaras en ningún momento de la presentación, ni un solo seguimiento; por el contrario, se usaron cámaras estáticas orientadas en diferentes posiciones lateralmente de acuerdo al expositor y el lugar asignado.

La rigidez en las tomas y la falta de dinamismo durante todo el evento propició que la secuencia televisiva sea lenta y, por momentos, estática. Además, esto generó que algunas de las intervenciones carezcan de ritmo volviéndose monótonas, sobre todo si se suma a esto el escaso manejo del lenguaje audiovisual de los participantes. De acuerdo a la bibliografía recogida, los acontecimientos de este tipo no tienden a presentar una amplia cobertura en el juego de cámaras y movimientos que contribuyan a la espectacularización del certamen como programa televisivo, pero sí un mayor 
despliegue audiovisual y con tomas de distintos ángulos que contribuyan a mantener la atención del espectador, dos aspectos claves de los que careció la "Exposición de motivos".

\section{SÍNTESIS DE RESULTADOS}

De esta manera, se desarrollan los resultados obtenidos en relación a los tres objetivos específicos planteados: se tiene que la estrategia discursiva más utilizada fue el ataque, que la mayoría de las intervenciones fueron de carácter político y que se usaron planos medios completamente rígidos para el encuadre de los participantes. Asimismo, se infiere un ataque político por parte del "Sî́ y una aclamación político- personalista por parte del "No". Es así que, con estos hallazgos, se procederá a la contrastación de las hipótesis en el capítulo final de la presente investigación.

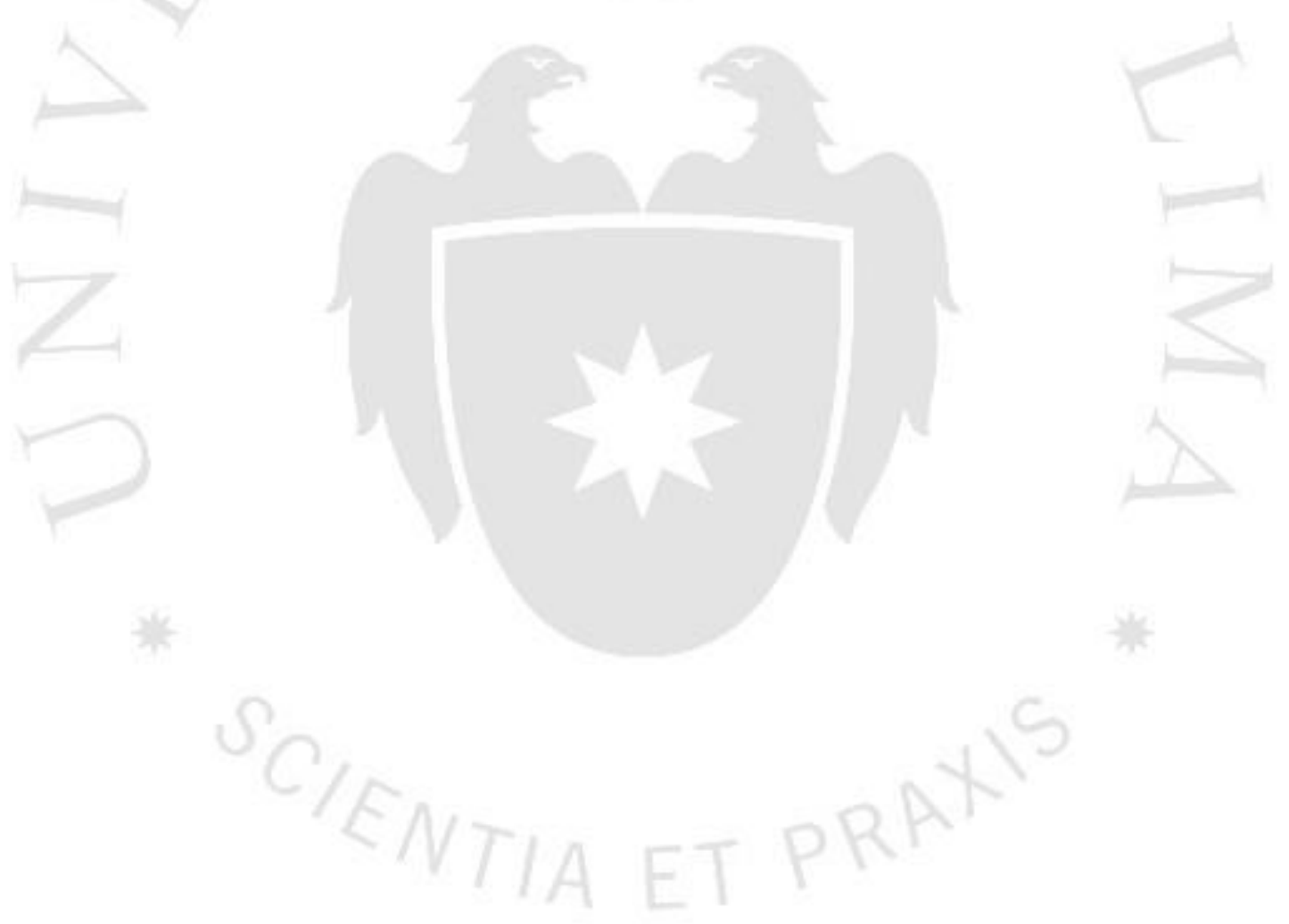




\section{DISCUSIÓN}

Una vez finalizado el análisis de los resultados y en función a la teoría recogida de los distintos autores mencionados acerca de la fragmentación partidaria, la volatilidad electoral, la revocatoria y los debates televisados, se da inicio a la parte central de esta investigación. A continuación, se procede a la validación de las hipótesis establecidas y a determinar en qué medida es que se dieron.

En orden al primer objetivo específico planteado, se postuló que "la estrategia discursiva más usada durante el evento es la aclamación”, lo que resultó falso. Se obtuvo que el "Sî́" articuló su discurso únicamente en el ataque, mientras que el "No" usó más la aclamación y, prácticamente en la misma medida, las estrategias de ataque y defensa. La investigación realizada por Téllez, Muñiz y Ramírez (2010) había arrojado que la estrategia discursiva más empleada en los debates electorales en Estados Unidos y en México era la aclamación; sin embargo, en esta ocasión la más utilizada fue el ataque. Algo que resultaba ciertamente previsible teniendo en cuenta que, al tratarse de una revocatoria, el discurso se iba a tornar un tanto más agresivo.

Lo hallado con respecto a la estrategia discursiva más utilizada durante el evento, siendo el ataque la principal, es un resultado que puede ser analizado desde otras perspectivas, no tiene que darse necesariamente de la misma forma en episodios similares y no tiene que ser obligatoriamente aplicable al resto de eventos electorales o debates; ya que, si bien es cierto que fue la estrategia más recurrente considerando a las dos agrupaciones, no fue la más empleada por el "No". Esta agrupación hizo mayor uso de la estrategia de aclamación, evitando estar a la defensiva. Además, cabe considerar que este punto representa a la única hipótesis que no se cumplió.

Para la segunda hipótesis, se planteó que "las intervenciones con orientación temática hacia la política son las más utilizadas por los participantes” y se obtuvo que fue verdadera. Se halló que la mayoría de las intervenciones de ambas agrupaciones fue de orientación política. En general, de las setenta y seis intervenciones que se segmentaron, cuarenta y seis fueron en alusión a la política y treinta, en referencia a la autoridad. El mismo estudio de Téllez, Muñiz y Ramírez (2010) arrojó que se usan en mayor medida los discursos en relación a la política que a la autoridad. 
En el marco de la revocatoria, resulta lógico que se aluda más a la gestión de Susana Villarán que a su propia figura como alcaldesa. Con el objetivo de revocarla o de mantenerla en el cargo, según cada miembro del "Sî́ y del "No", mencionar acontecimientos a favor o en contra durante la gestión puede resultar favorable según el objetivo. Por el contrario, cuando la intervención se refiere a la autoridad, la agrupación que la realiza no suele verse favorecida electoralmente, tal y como también aparece en la investigación de Téllez, Muñiz y Ramírez (2010). Al contrario de lo que el sentido común del periodismo acusa, con lo hallado se puede argumentar que la clase política sí tiende a exponer y a discutir sus ideas en épocas electorales, ya sea que el motivo fuera un proceso de revocatoria.

La última hipótesis abordada consistió en el estudio sobre el lenguaje audiovisual, donde se tiene que "los planos empleados durante la transmisión del evento facilitan la comunicación no verbal”. Esta hipótesis no ha podido ser comprobada del todo, ya que no se cuenta con mucha información con respecto a las técnicas audiovisuales del certamen, solo se tiene una aproximación general de los hechos televisados. Sin embargo, hasta cierto punto se puede especular con que la premisa sí se cumple, debido a la similitud entre los planos usados durante la "Exposición de motivos" y los que figuran en el estudio de Eva Quintas y Natalia Quintas (2010) sobre la aparición de un personaje debatiendo o exponiendo en el marco de una contienda electoral.

Siendo así que, se emplearon planos medios — de la cintura para arriba - para enfocar a cada uno de los siete participantes en pantalla, no hubo otro tipo de plano durante las intervenciones. El intercambio de miradas entre candidatos es mínimo y no se representa a través de las cámaras, evitando el diálogo entre integrantes de las agrupaciones y favoreciendo la exposición al público (Kanashiro, 2014, p. 13). Todo esto sumado a que el encuadre siempre estuvo fijado en el eje central de la toma y se le otorgó un solo plano a cada participante, lo cual le dio sencillez y monotonía a las intervenciones, a falta de distintos planos y movimientos de cámara. Por consiguiente, Kanashiro también halla que el debate mantiene "un permanente ritmo narrativo parsimónico, sujeto en gran medida a la segmentación propia de la televisión” (2014, p. $10)$.

La teoría sobre conceptos del lenguaje audiovisual de Eva Quintas y Natalia Quintas (2010) señala que los planos cercanos siempre generan sensaciones próximas y 
verosímiles con quien está en pantalla, debido a que se puede apreciar mejor ciertos gestos que denotan confianza y empatía, lo que conlleva a influir en una intención de voto. Así, se tienen tomas rígidas y centradas frontalmente que, junto a la información obtenida sobre la intervención de cada uno de los participantes, permite deducir que la hipótesis está próxima a cumplirse.

Por parte del estudio del lenguaje audiovisual, no se sostiene a ciencia cierta la certeza de que lo obtenido sea definitorio porque, como ya se ha mencionado, los elementos a analizar fueron mínimos y carecieron de detalles que permitieran una mejor descripción de los planos. Además, no se encontraron demasiadas fuentes bibliográficas que abordaran el tema de tal manera que se pueda hacer una verificación concluyente acerca de esta hipótesis. Para profundizar en este aspecto y lograr resultados más definitorios (y con un alto índice de precisión) se requiere de metodologías cualitativas más exhaustivas.

Finalizando con las validaciones, está la hipótesis general, cuya formulación deriva en el tema principal de la presente investigación. Se plantea que "en el marco de una revocatoria, los debates televisados cumplen el papel de una exposición de motivos”. Esta hipótesis resulta verdadera en la medida en que se cumplió con los tres objetivos específicos planteados desde un inicio: se conoció la estrategia discursiva más utilizada, se clasificó la orientación temática de las intervenciones y se determinó, en cierta medida, si las tomas favorecieron la comunicación no verbal. La "Exposición de motivos", como parte del proceso de revocatoria, fue una muestra de la libertad de expresión y de participación por parte de las autoridades en beneficio de la ciudadanía (factores que reflejan el cumplimiento de máximas en una democracia directa).

El concepto idóneo (teniendo como referencia el modelo norteamericano) y común que se tiene del debate implica la participación de candidatos que tienen como objetivo ganar una elección. Además, el formato que presentan este tipo de debates posee una estructura definida, sin tiempos muertos y, ni mucho menos, ausentismo de los participantes. Los debates denominados como tradicionales, que se desarrollan en las investigaciones de Planas (1998) y Montoya (2012), presentan a dos contendores representando a grupos políticos que buscan persuadir a los telespectadores que voten por ellos para llegar a un puesto de gobierno. Mientras que en el evento estudiado se tuvo a dos colectivos poco organizados en busca de relevar o mantener a una autoridad. Las agrupaciones expositoras, el "Sî́” y el "No", carecían de una representatividad 
partidaria y electoral: el primero jugaba bajo los intereses políticos de partidos como el Apra o figuras como Luis Castañeda. Precisamente, este último fue señalado por los regidores durante el acotencimiento estudiado de organizar la revocatoria y estar asociado con Marco Tulio Gutiérrez, quien en todo momento negó cualquier tipo de vinculación con el predecesor de Villarán, hecho que hasta la fecha no ha podido ser comprobado ni aceptado por ninguno de los dos.

No hubo deliberaciones fundadas en argumentos concisos que signifiquen una alternativa atractiva y digna de ser atendida por el público expectante; sino que se dio una exposición de motivos a favor y en contra de la revocatoria. Además, otro aspecto relevante para distinguir el papel de este debate es que los participantes mantuvieron un orden establecido y jerárquico en sus intervenciones; no hubo respuestas directas ni discursos naturales orientados por las circunstancias, ya que el formato no contemplaba las réplicas, solo la exposición.

El grado de certeza que se tiene con lo obtenido de acuerdo al objetivo principal de la investigación es muy elevado, ya que lo acontecido no tiene similitudes ni guarda relación que conlleve a alguna afirmación dudosa sobre el papel de un debate en un proceso de revocatoria. En ese sentido, el evento motivo de la investigación difiere con el del debate tradicional. El título ("Exposición de motivos") que se le adjudicó desde el principio es el más apropiado para enmarcar en qué consistió el debate en los márgenes de una revocatoria.

Esta investigación acerca del Proceso de revocatoria a Susana Villarán De La Puente: el debate en la "Exposición de motivos" ha sido muy importante para poder diferenciar a dicho evento del debate tradicional. También se ha podido conocer cómo este mecanismo permite que los participantes empleen diferentes estrategias en su discurso y las orienten bajo una determinada temática. Con lo estudiado, se ha llegado a comprender cómo se desarrolla la revocatoria y la importancia que le otorga la clase política al tratarse de un mecanismo válido en una democracia directa. Además, se ha distinguido el lenguaje audiovisual simple y el rígido juego de cámaras que se usa para este tipo de acontecimientos. Con el presente trabajo, se ha logrado analizar el nivel político de algunas autoridades, partidos políticos y personajes públicos, así como la seriedad con la que toman procesos tan delicados, pero a la vez significativos, para el futuro de la ciudadanía. 


\section{REFERENCIAS}

Amaya, L. \& G. Berrío-Acosta (2015). Modelo de tres niveles para el análisis de casos éticos en psicología. Disponible en: < http://eticapsicologica.org/wiki/images/f/f2/1501_Modelo_MTN.pdf>.

Campos, M. (ed.) (2012). Democracia, humanismo y política: homenaje a Pedro Lamas. Lima: Universidad de Lima.

Contreras, J. (1990). Vida política y televisión. Madrid: Espasa Calpe.

Crespo, I. (2011). Manual de comunicación política y estrategias de campaña: candidatos, medios y electores en una nueva era. Buenos Aires: Biblos.

Dargent, E. (2012). Contra-historia del Perú: ensayos de historia política peruana. Lima: Mitin.

Dargent, E. (2013). Demócratas precarios: élites y debilidad democrática en el Perú y América Latina. Lima: IEP.

Degregori, C. (1991). Demonios y redentores en el nuevo Perú: una tragedia de dos vueltas. Lima: IEP.

Degregori, C. \& C. Meléndez (2007). El nacimiento de los otorongos. Lima: IEP.

Domínguez, C. (2014). Los debates presidenciales de 2012 y su contribución a la cultura política democrática. Global Media Journal México, 11(21), 1-24.

Echevarría, M. \& B. Chong (2013). Debates presidenciales y calidad de la democracia. Análisis empírico normativo de los debates mexicanos de 2012. Palabra Clave, $16(2), 341-365$.

Fowks, J. (2015). Chichapolitik: la prensa con Fujimori en las elecciones 2000 en Perú. Lima: Fundación Friedrich Ebert.

González, A. (2008). La implicación ciudadana en el gobierno local: del debate teórico a la experiencia participativa. Lima: JNE

Ipsos Apoyo (2010). Avanza Toledo [encuesta]. Opinión data, 10(130). Disponible en: $\langle$ http://www.ipsos.pe/sites/default/files/opinion_data/avanza-toledo.pdf $>$. 
Kanashiro Nakahodo, L. (2014). Debates electorales televisados: el puritanismo político audiovisual peruano. Lima: PUCP.

Kanashiro, L. (2015). Debates presidenciales televisados en el Perú (1990-2011): una aproximación semiótica. Lima: Universidad de Lima.

Levitsky, S. \& J. Loxton (2013). Populism and competitive authoritarianism in the Andes.

Democratization, 20(1), 107-136. Disponible en: <http://scihub.cc/10.1080/13510347.2013.738864>.

Luengo, O. (2011). Debates electorales en televisión: una aproximación preliminar a sus efectos inmediatos. Revista Española de Ciencia Política, 25, 81-97.

Manent, M. (2014). Mayoría absoluta Disponible en: $<$ http://www.derecho.com/c/Mayor\%C3\%ADa_absoluta> (consultado el 20 de enero de 2017).

Montoya, U. (2012). Revocatoria, vacancia y suspensión de autoridades regionales y municipales. Lima: Márquez Editores.

Pásara, L. (1988). Democracia, sociedad y gobierno en el Perú. Lima: Centro de Estudios de Democracia y Sociedad.

Pérez-Ruiz, M. \& F. Melgosa (2015). Los debates electorales realizados en España en 2008: cuando la política se convierte en espectáculo televisado. Contratexto, 24, 113-132.

Planas, P. (1998). Comunicación política y equidad electoral. Lima: Universidad de Lima.

Planas, P. (2001). La videopolítica en el Perú: las elecciones y el acceso de los partidos y los candidatos en el inicio de la TV peruana. Lima: Universidad San Martín de Porres.

Quintas, E. \& N. Quinas (2010). Cara a cara electoral televisado: análisis audiovisual de los debates presidenciales. Miguel Hernández Communication Journal, 2, 20-39.

Salcedo, J. (1990). Tsunami presidente: conversación privada con el Presidente, la madrugada de su elección. Lima: Venus.

Sartori, G. (2003). Videopolítica. Medios, información y democracia de sondeo. México DF: Instituto Tecnológico y de Estudios Superiores de Monterrey. 
Silva, A. (2002). Control social, neoliberalismo y derecho penal. Lima: Fondo Editorial UNMSM. Disponible en: $<$ http://sisbib.unmsm.edu.pe/bibvirtual/libros/sociologia/control_social_neo/Po rtada.htm>.

Tanaka, M. (1998). Los espejismos de la democracia: el colapso del sistema de partidos en el Perú 1980-1995 en perspectiva comparada. Lima: IEP.

Tanaka, M. (2005). Democracia sin partidos Perú, 2000-2005: los problemas de representación y las propuestas de reforma política. Lima: IEP.

Tellería, M. (2007). Los medios de comunicación al servicio del poder: la influencia mediática en la sociedad global. Barcelona: Erasmus.

Téllez, N., C. Muñiz \& J. Ramírez (2010). Función discursiva en los debates televisados. Un estudio transcultural de los debates políticos en México, España y Estados Unidos. Palabra Clave, 13(2), 251-270.

Tuesta, F. (1995). Sistema de partido políticos en el Perú 1978-1995. Lima: Fundación Friedrich Ebert.

Tuesta, F. (2005). Representación política: las reglas también cuentan: sistemas electorales y partidos políticos. Lima: PUCP.

Tuesta, F. (2014). Una onda expansiva. Las revocatorias en el Perú y América Latina. Lima: JNE.

Vargas Llosa, M. (2010). El pez en el agua. Lima: Alfaguara. 


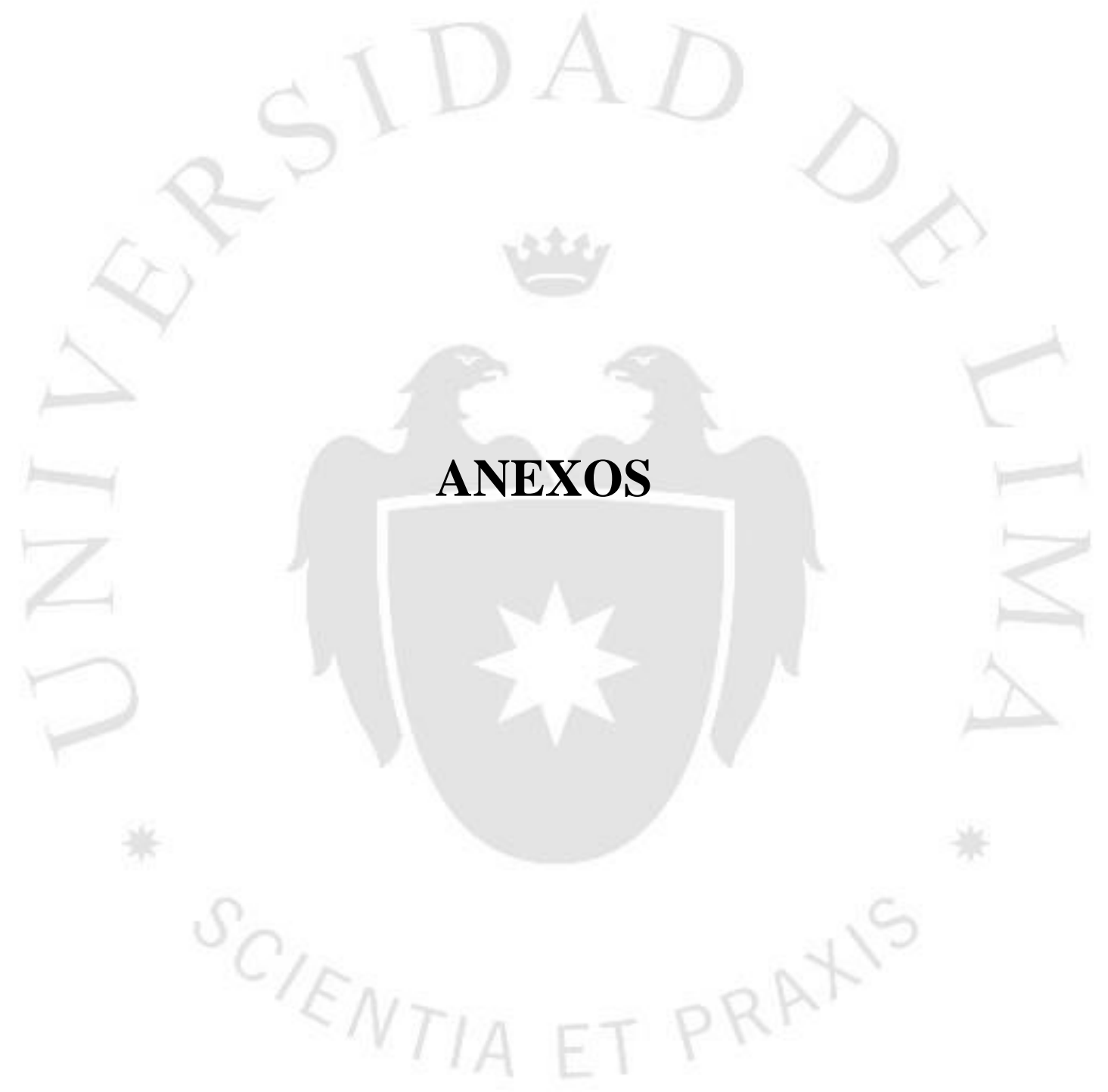




\section{ANEXO 1: LIBRO DE CÓDIGOS}

Criterio para la clasificación de los enunciados según la estrategia discursiva:

Ataque: confrontaciones por medio de argumentos o cuestionamientos que buscan desfavorecer al contrincante. Como por ejemplo adjetivos pretensiosos, preguntas mal intencionadas, desmerecimientos y difamaciones.

Aclamación: alusiones positivas del participante con respecto a acciones y decisiones políticas, y las consecuencias de las mismas. Se reconocen y resaltan los puntos fuertes que tuvo la gestión, puede ser alguna obra, alguna medida o disposición, etc.

Defensa: respuestas y reacciones inmediatas ante un ataque del oponente, a fin de evitar mayores daños y restaurar la imagen positiva del principio.

Concordancia: comentarios o aseveraciones que buscan entablar algún tipo de acuerdo o puntos en común entre participantes.

Criterio para la clasificación de los enunciados según la orientación temática:

Política: alusiones a la gestión de las autoridades.

Candidato: alusiones directamente a la persona. 


\section{ANEXO 2: ANÁLISIS AUDIOVISUAL}

1. Intervenciones de Federico Salazar, moderador del debate.

\begin{tabular}{|c|l|}
\hline $\begin{array}{c}\text { NÚMERO DE } \\
\text { PLANOS }\end{array}$ & 2 \\
\hline TOMA & Plano medio y plano general. \\
\hline ÁNGULO DE LA \\
CÁMARA
\end{tabular}
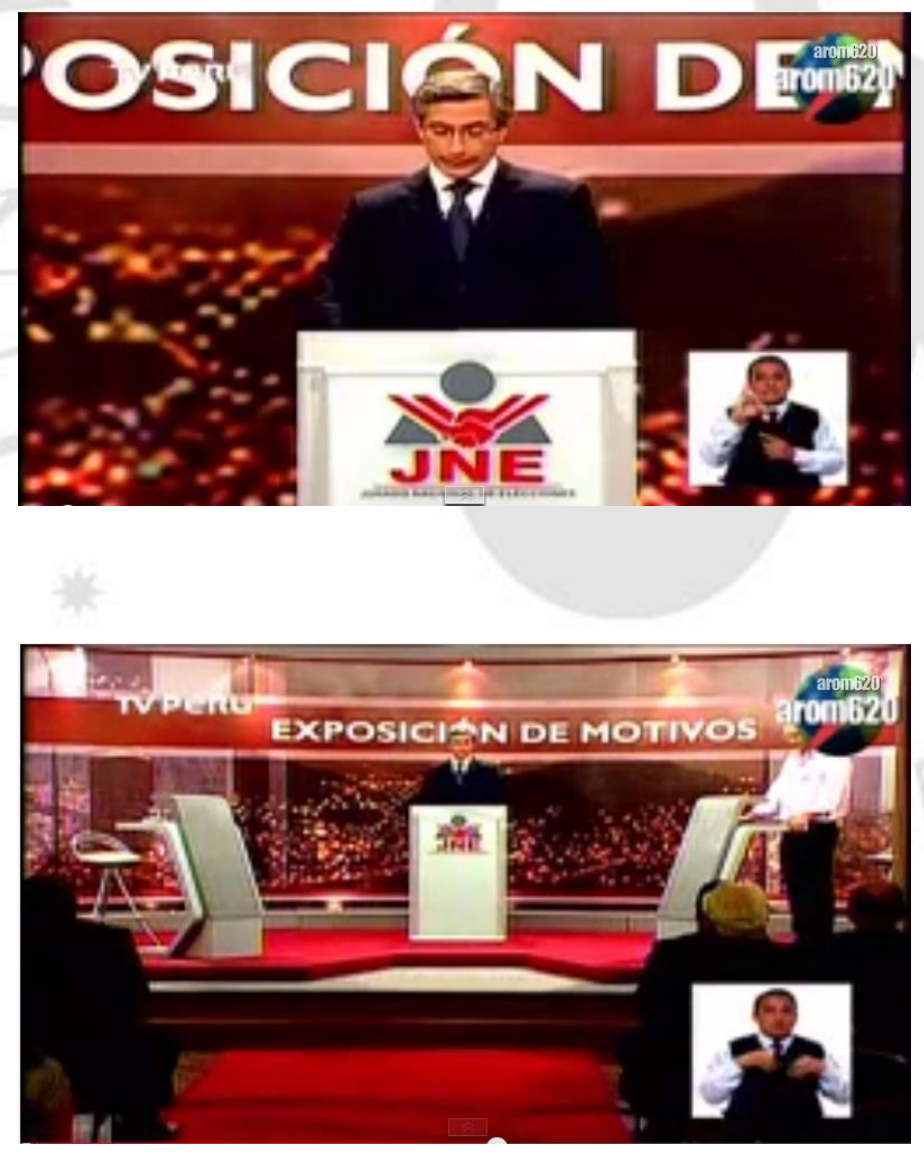

2. Intervenciones de Patricia Juárez. 


\begin{tabular}{|c|l|}
\hline $\begin{array}{c}\text { NÚMERO DE } \\
\text { PLANOS }\end{array}$ & 1 \\
\hline TOMA & Plano medio. \\
\hline ÁNGULO DE LA & De derecha a izquierda. \\
CÁMARA & Eje central. \\
\hline ENCUADRE & 8 \\
\hline NÚMERO DE & \\
\hline
\end{tabular}

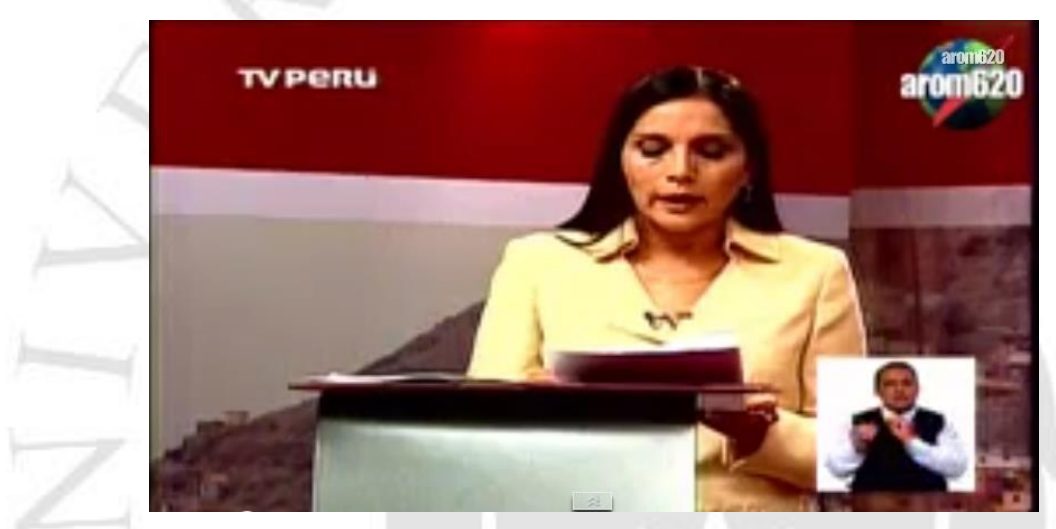

3. Intervenciones de Eduardo Zegarra.

\begin{tabular}{|c|c|}
\hline $\begin{array}{c}\text { NÚMERO DE } \\
\text { PLANOS }\end{array}$ & 1 \\
\hline TOMA & Plano medio. \\
\hline ÁNGULO DE LA & De izquierda a derecha. \\
\hline EÁMARA & Eje central. \\
\hline NÚMERO DE & 6 \\
\hline INTERVENCIONES & \\
\hline
\end{tabular}




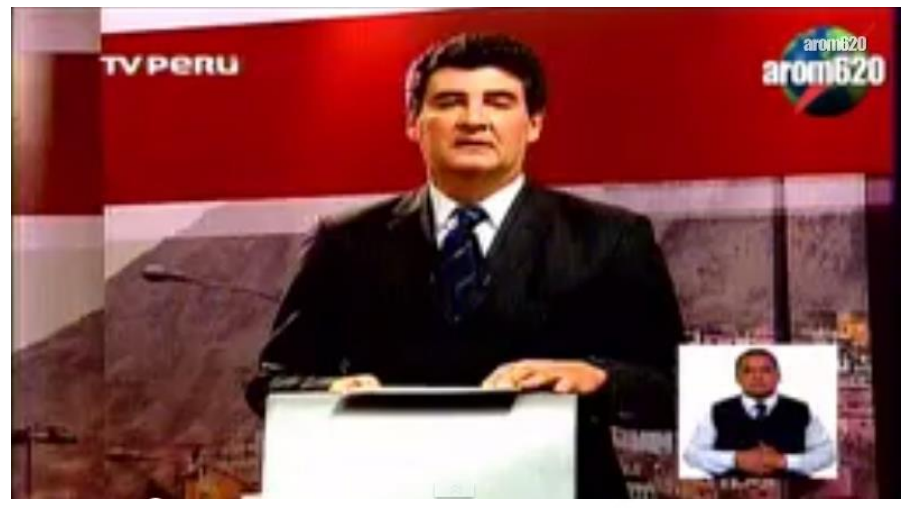

4. Intervenciones de Marisa Glave.

\begin{tabular}{|c|c|}
\hline $\begin{array}{c}\text { NÚMERO DE } \\
\text { PLANOS }\end{array}$ & 1 \\
\hline TOMA & Plano medio. \\
\hline ÁNGULO DE LA & De izquierda a derecha. \\
\hline CÁMARA & Eje central. \\
\hline ENCUADRE & 4 \\
\hline INTERVENCIONES & DE \\
\hline
\end{tabular}

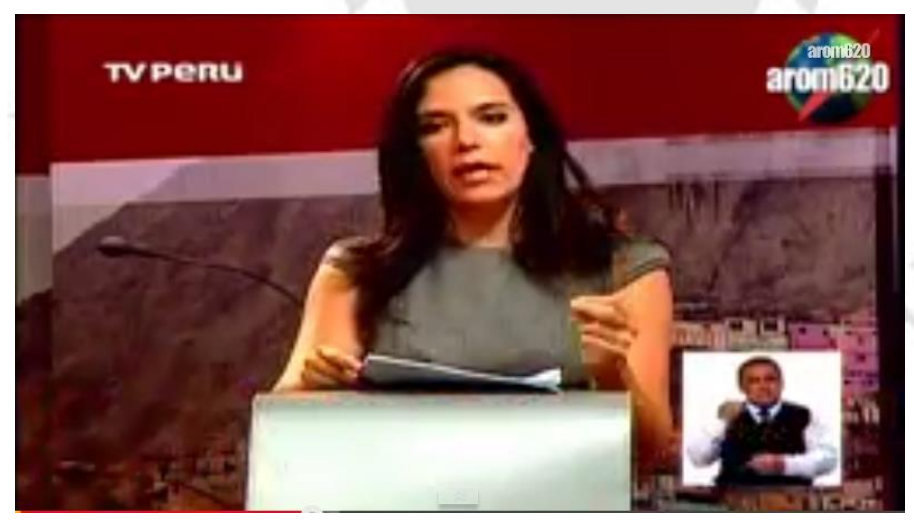

5. Intervenciones de Pablo Secada.

\begin{tabular}{|ll|l|}
\hline \begin{tabular}{|l|l|} 
NÚMERO DE \\
PLANOS
\end{tabular} & 1 \\
\hline
\end{tabular}




\begin{tabular}{|c|l|}
\hline TOMA & Plano medio. \\
\hline ÁNGULO DE LA & De izquierda a derecha. \\
\hline ENCUADRE & Eje central. \\
\hline NÚMERO DE & 3 \\
\hline
\end{tabular}

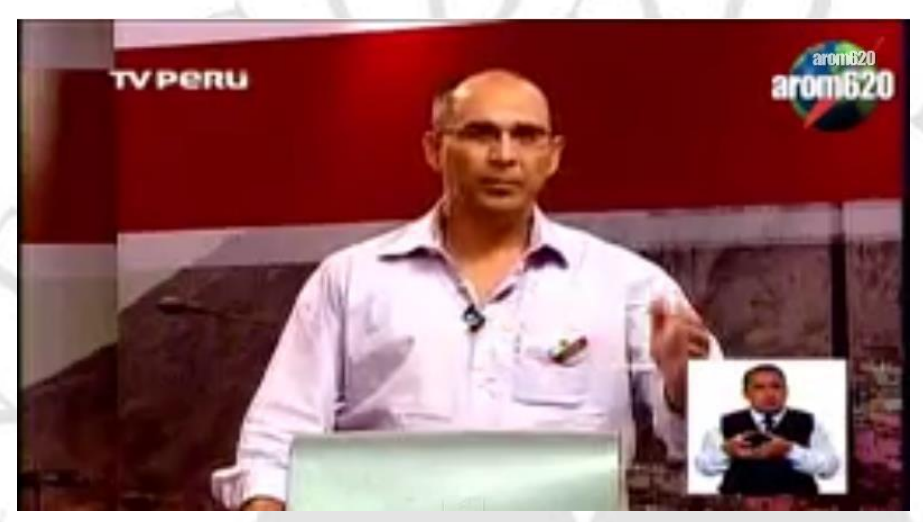

6. Intervenciones de Iván Becerra.

\begin{tabular}{|c|c|}
\hline $\begin{array}{c}\text { NÚMERO DE } \\
\text { PLANOS }\end{array}$ & 1 \\
\hline TOMA & Plano medio. \\
\hline ÁNGULO DE LA & De izquierda a derecha. \\
\hline CÁMARA & Eje central. \\
\hline ENCUADRE & 4 \\
\hline INTERMERO DE & \\
\hline
\end{tabular}




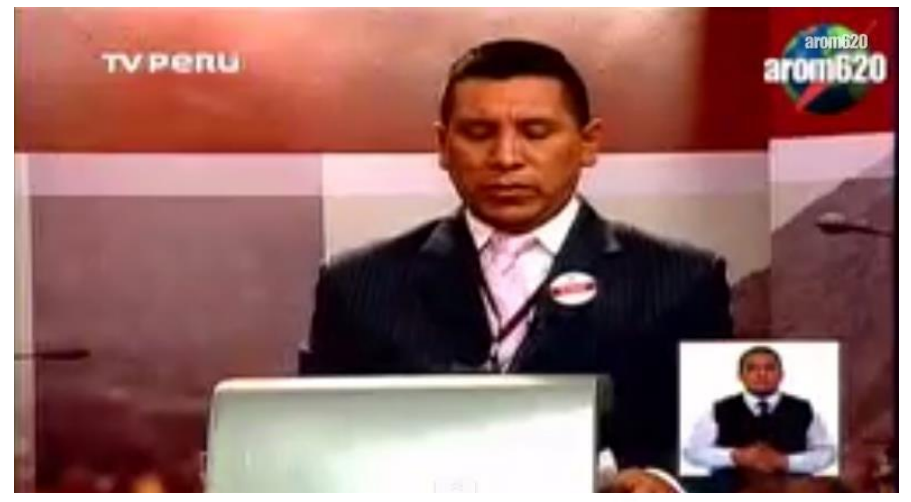

7. Intervenciones de Luis Castillo.

\begin{tabular}{|c|l|}
\hline $\begin{array}{c}\text { NÚMERO DE } \\
\text { PLANOS }\end{array}$ & 1 \\
\hline TOMA & Plano medio. \\
\hline ÁNGULO DE LA & De izquierda a derecha. \\
\hline CÁMARA & Eje central. \\
\hline ENCUADRE & 3 \\
\hline INTERVENCIONES & DE \\
\hline
\end{tabular}

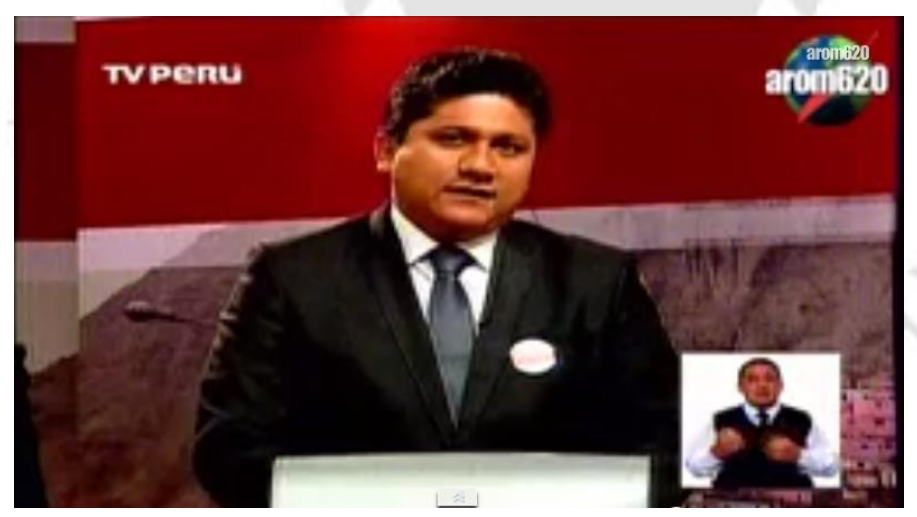

8. Intervenciones de Luis Calvimontes.

\begin{tabular}{|ll|l|}
\hline NÚMERO DE & 1 \\
PLANOS & & \\
\hline
\end{tabular}




\begin{tabular}{|c|l|}
\hline TOMA & Plano medio. \\
\hline ÁNGULO DE LA & De izquierda a derecha. \\
\hline ENCUADRE & Eje central. \\
\hline NÚMERO DE & 1 \\
\hline
\end{tabular}

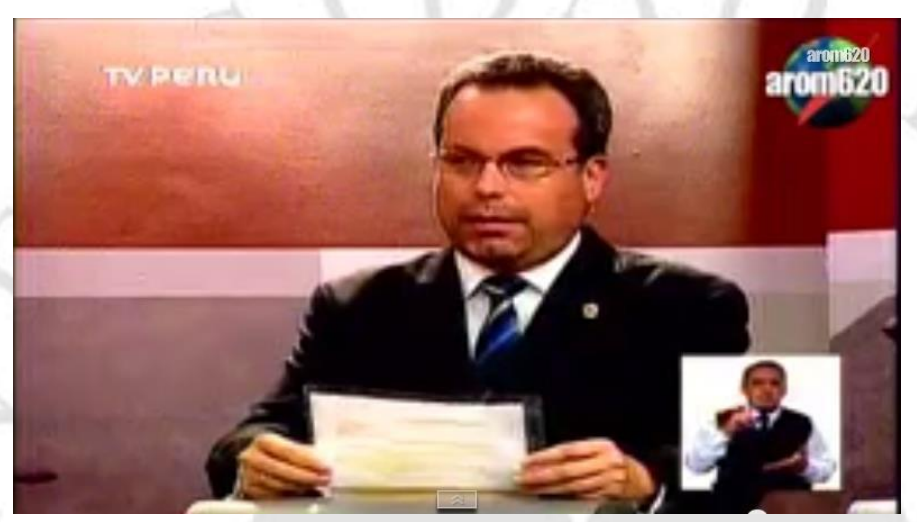




\section{ANEXO 3: TRANSCRIPCIÓN COMPLETA DE LA "EXPOSICIÓN DE MOTIVOS"}

Federico Salazar: Muy buenas noches, bienvenidos al programa Voto Informado del Jurado Nacional de Elecciones. El próximo domingo vamos a tener la opción y la oportunidad de votar en Lima Metropolitana, porque si se revoque a las autoridades metropolitanas o porque no se revoque a dichas autoridades. Esta es la primera elección de este tipo en nuestra ciudad capital y está amparada en los derechos ciudadanos reconocidos en la Constitución y en la ley, por eso pensamos que es muy útil y muy importante realmente conocer los motivos de los que están por el SÍ revocatorio y los motivos de quienes están por el NO a la revocación. Esta exposición de motivos es fruto de los compromisos del pacto ético electoral y es el resultado del diálogo, el consenso y acuerdos firmados por las partes convocadas. Participan los representantes del comité promotor de la revocación y los representantes de la alcaldesa y los regidores de las diferentes fuerzas política que componen el Consejo Municipal de Lima Metropolitana. Vamos a organizarnos de la siguiente manera, vamos a tener seis bloques. En el primero se responderá la pregunta ¿Debe dejar el cargo la alcaldesa? En el segundo, tercer y cuarto bloque se responderá la pregunta ¿Debe dejar el cargo de regidor? Y finalmente, en los bloques quinto y sexto darán un mensaje final los representantes del comité promotor de la revocación y los representantes de la alcaldesa y los regidores. Pero antes de empezar debo dar lectura a la solicitud que dio inicio a este proceso electoral, la solicitud la presentaron el señor Carlos Vidal Vidal y su representante el señor Marco Tulio Gutiérrez el 26 de octubre del 2012 ante la entonces jefa de la ONPE. El señor Carlos Vidal Vidal expuso lo siguiente

- Ante usted me presento y solicito se inicie el proceso de revocatoria de autoridades metropolitanas provincia de Lima y departamento de Lima. Las autoridades a ser revocadas son Susana Villarán de la Puente, cargo alcaldesa, y todos los regidores del Consejo Metropolitano de Lima. Motivos ineficiencia en el desempeño de sus funciones. Firman promotor y su representante. Se adjunta constancia de haber alcanzado el mínimo de firmas requeridas, las actas de verificación de RENIEC y fotocopia del DNI. Ahora sí, quiero presentarles a los que deben ser los protagonistas de esta noche. Por el comité promotor de 
la revocación se acordó que fueran Patricia Juárez Gallegos, Miguel Ángel Saldaña Reátegui y Luis Alberto Tudela Varela. Por las autoridades en consulta se acordó que fueran Eduardo Ariel Zegarra Méndez, Merisa Glabe Rémi, Pablo Alberto Secada Helguera, Iván Becerra Hurtado, Luis Felipe Castillo Oliva y Luis Felipe Calvimontes Barrón. Sin más de por medio vamos a dar pase entonces a esta exposición de motivos con la primera pregunta, adelante control.

\section{APARECE EN PANTALLA LA PRIMERA PREGUNTA}

Federico Salazar: Muy bien, según lo acordado es el turno de la señora Patricia Juárez, representante del comité promotor, tiene tres minutos con cincuenta, buenas noches.

Patricia Juárez: Buenas noches. Muy buenas noches a todos. Cuanto hubiera querido el pueblo de Lima, los hogares que nos están viendo esté presente la señora alcaldes Susana Villarán de la Puente. Entendemos que no es un gesto de soberbia, será por otras razones que seguramente la mantienen ocupada. Es un honor para quienes acompañamos el sentimiento popular de rechazo a la gestión de la alcaldesa Villarán, estar presentes para argumentar esta interpelación que hace el poblador de Lima hacia la señora Villarán y sus regidores. Una primera explicación que el pueblo de Lima quiere pedirle es saber por qué una cantidad mayoritaria de limeños están descontentos, tienen una percepción negativa hacia la gestión que usted lidera ¿Será porque sienten no gestionó de manera adecuada la ciudad? ¿Qué no estuvo cerca de ellos para solucionar los problemas de inseguridad ciudadana? ¿Falta de agua? ¿Carencia de infraestructura vial? ¿Obras no continuadas o comenzadas pero no concluidas? ¿Y una pésima gestión de los recursos de la Municipalidad? Señora Villarán de la Puente ipor qué mintió una vez más indicando que se habían hecho cuatro nuevos Hospitales de la Solidaridad, cuando lo que se hizo fue cerrar algunos y trasladarlos íntegramente a otro lugar? El único nuevo que se ha hecho es el de Villa María, con un convenio que quedó listo de la gestión pasada. Señora Villarán de la Puente los pobladores de Lima quieren saber ¿por qué prometió en campaña liderar la lucha contra la inseguridad ciudadana y no ha cumplido? ¿por qué no tenemos mapas del delito como prometió? No tenemos policía metropolitana como prometió ¿por qué nunca presentó la iniciativa legislativa ante el Congreso? No tenemos puestos de auxilio rápido, tenemos la escuela de serenos en abandono y nos engañó a todos los limeños con patrulleros sin SOAT 
ni placas y circulinas alquiladas, motos en uso sin choferes ¿por qué no cumplió sus promesas y nos condena a los limeños a ser blanco de la delincuencia? Señora Susana Villarán de la Puente, la población de San Juan de Lurigancho me pide preguntarle ¿por qué paralizó el túnel Santa Rosa por cuatro años, con gastos que superan los cuatrocientos millones de soles, que pagaremos todos nosotros los limeños y los condena a un tráfico infernal en la zona de Acho, restándole tiempo para el disfrute con sus familias y tampoco realizó obra pública importante en este distrito de hombres y mujeres emprendedores y respetables que constituyen el nuevo rostro del Perú? Señora Villarán de la Puente, los vecinos de Villa El Salvador, San Juan de Miraflores y Villa María del Triunfo me piden preguntarle ¿por qué después de quince meses aún no logran concluir la Costa Verde Sur, en playas Barlovento y Venecia cuando anunció en noviembre del 2011 que lo haría en tres meses? Hoy luce abandonado, incumpliendo con la promesa de darles la playa que merecen las clases menos favorecidas. Señora Villarán de la Puente, los vecinos más necesitados me piden preguntarle ¿por qué en dos años solo hizo 167 escaleras y 3 muros de contención y no 1200 escaleras como nos mintió, engañando a la población y por qué no se ha hecho ningún parque zonal cuando CERPARQ gasta $1800000 \mathrm{n}$ publicidad que podría haber invertido en 2 parques zonales? El pueblo de Lima espera una respuesta, que espero les sea satisfactoria, no queremos que nos digan ¿qué proyectos esperan hacer, sino qué hicieron? Por las razones expuestas el pueblo la va a revocar señora Susana Villarán de la Puente.

Federico Salazar: Muchas gracias señora Patricia Juárez, es el turno del señor Eduardo Zegarra como representante de la alcaldesa, tiene para su comentario un minuto treinta.

Eduardo Zegarra: Buenos días Federico. Buenos días, buenas noches perdón señora Juárez. Buenas noches a los vecinos y vecinas de Lima. Soy el teniente alcalde de Lima y he venido a representar y a defender la gestión de nuestra alcaldesa Susana Villarán. He escuchado con atención la lista de argumentos de la señora. Debo decir que en algunos casos puede tener razón pero en muchos no. Nuestra gestión trabaja por Lima, lo hace con honestidad y eficiencia. Susana Villarán ha iniciado la reforma del transporte para enfrentar el caos más grave de nuestra ciudad. Susana asumió este gran reto, lo hizo con el coraje de la mujer peruana. Susana dio la cara por Lima y derrotó, con nosotros, con ustedes nueve paros de transporte. $\mathrm{Y}$ por eso es que hemos podido ordenar decenas de rutas $\mathrm{y}$ 
reordenamos el tránsito en avenidas tan importantes como la Abancay, la Túpac Amaru, Tacna, Manco Cápac, la avenida Canadá. Hoy, ya medio millón de pasajeros ahorran tiempo y dinero por estas medidas. Yo creo que nadie en nuestra ciudad quiere que dejemos a medio camino la reforma de transporte que hemos iniciado. Ahora quisiera hacerle una pregunta, que me gustaría me responda usted señora ¿apoya usted la reforma de transporte o apoya los paros y el caos en nuestra ciudad?

Federico Salazar: Muy bien, muchas gracias. Ahora la respuesta de Patricia Juárez, un minuto.

Patricia Juárez: Todos apoyamos la reforma del transporte por supuesto pero bien hecha. Señora Villarán los vecinos de Lima quieren saber ¿por qué subirán los peajes, se crearán nuevos peajes y por qué se entregaron las vías de Lima a empresas brasileñas por 30 años por incapacidad de su gestión de hacer obra pública? Señora Villarán, los 200 mil pasajeros por día que habrían sido los usuarios de la línea 2 del Metropolitano le preguntan ¿por qué los perjudicó desapareciendo ese proyecto que era parte de la concesión Línea Amarilla, cambiándolo a su capricho por un parque, cambiándole además de nombre y dándole 10 años más de concesión, es decir 160 millones de dólares a la empresa OAS, hecho que está denunciado al Ministerio Público? Señora Villarán, los usuarios del Metropolitano quieren saber ¿por qué ha subido a 2 soles el pasaje, perjudicándolos económicamente y por qué tenemos que pagarles a los operadores del Metropolitano 200 millones por no cumplir con compromisos del contrato?

Federico Salazar: Su tiempo ha vencido. Señor Eduardo Zegarra usted ahora 3 minutos 50 para una exposición.

Eduardo Zegarra: Nuestra gestión ha potenciado lo bueno que encontramos y corregido sus errores pero, además, ha generado nuevos proyectos para el beneficio de todos. Hemos construido 4 hospitales, escuche bien señora Juárez han sido construidos 4 hospitales que ahora superan el millón de atenciones. Ahora los limeños más pobres pueden usar gratis el seguro integral de salud, para atenderse en los hospitales de la Municipalidad y comprar medicamentos genéricos a un precio 30 menor que los medicamentos de marca en las farmacias. Susana Villarán ha iniciado la reforma del transporte, uno de los cambios más esperados y necesarios para nuestra ciudad. Hemos incorporado 18 rutas alimentadoras 
al Metropolitano y subimos el número de usuarios de este servicio de 200 mil a medio millón de pasajeros al día. Con esto, hemos reducido el tiempo que cada uno de nosotros gasta en transportarse y hoy un millón y medio de personas pierden menos tiempo por las medidas tomadas por nuestra gestión. Luego de arduos procesos de diálogo y concertación con todos los transportistas, se ha podido iniciar la gran transformación del transporte de Lima, con la licitación de 5 corredores complementarios, los corredores en Evitamiento, carretera Central, Javier Prado, La Marina, Brasil, Benavides. Estos grandes corredores solo funcionaran con rutas planificadas y no superpuestas con empresas que operan buses grandes y rápidos, con horario y paraderos, con choferes capacitados, trabajo digno y derechos laborales para todos. Este es el gran sistema integrado de transporte que atenderá 5 millones de personas, que le dará a Lima la oportunidad de dejar atrás el transporte caótico, el transporte inseguro que cada día genera accidentes y contaminación. Nosotros no buscamos esta revocatoria, ni pretendemos dividir Lima. Lima tiene que estar unida para enfrentar sus problemas como el caos del transporte, la inseguridad, la falta de agua, de vivienda, las carencias en salud y educación. Estos grandes problemas no los puede resolver la Municipalidad sola, requiere del concurso del gobierno nacional y de los distritos. También de todos ustedes vecinos y vecinas. Para enfrentar estos retos no podemos desunirnos, no podemos enfrentarnos unos a otros como si fuéramos enemigos. El mensaje de nuestra alcaldesa es de unidad y reconciliación. También es un pedido sincero para que dejen que nuestra gestión pueda desarrollar todo su potencial en los 4 años para los que ella y nosotros fuimos elegidos. Y lo ya logrado por Susana es más importante y lo estamos comunicando mejor. ¿Usted sabía que esta gestión ha conseguido que el sector privado invierta 7 mil millones de soles en infraestructura vial y urbana, un logro fundamental que le permite a Lima dar un salto hacia una ciudad más moderna e inclusiva? Con esto podremos ir de Ate al Callao en 20 minutos y las Panamericanas pasarán de tener 26 a 60 intercambios viales. Tendremos la extensión de la avenida Ramiro Prialé hasta Chosica y se construirán más de 150 kilómetros de nuevas vías que Lima, nuestra Lima tanto necesita. No entendemos señora, ¿por qué por intereses políticos se critica tanto estas inversiones para todos, realmente apoyan ustedes la inversión privada de Lima?

Federico Salazar: Muy bien, muchas gracias. El turno de la señora Patricia Juárez por un minuto con treinta. 
Patricia Juárez: A los amigos y amigas que me están escuchando, nos han querido manipular, que ahora que el pueblo dirá Sí a la revocatoria el caos se apoderará de la ciudad, esto es una falta de respeto, un desprecio al vecino por expresar una posición de rechazo a esta gestión. Señores, ya estamos viviendo en un caos, el Municipio de Lima somos casi 9 millones de personas que conformamos la ciudad. Con el debido respeto, el Municipio no es la señora Villarán y sus regidores. Ya se acabó el tiempo de los señores feudales o de los patrones de hacienda o capataces. Ahora todos somos iguales y todos los ciudadanos de Lima somos capaces de recomponer con compromiso y responsabilidad esta parálisis a la que está sometida la ciudad. El 65 por ciento de la población señala que la capacidad de conducción de la ciudad es muy mala por diversas razones, y eso tiene que remediarse de inmediato. Ya perdimos 2 años, no perdamos 4 porque la ciudad de Lima no lo soportará. Se menciona que este proceso costará mucho dinero, más dinero nos viene costando la inoperancia e incapacidad en la gestión de la señora Villarán de la Puente. Los procesos electorales tienen un costo y eso lo sabe bien los revocados, sin embargo manipulan con que las inversiones se paralizaran, les recuerdo que la institución Municipal es una sola, más allá de quien esté al frente las inversiones continuaran.

Federico Salazar: Su tiempo ha terminado. Es el turno del señor Eduardo Zegarra por un minuto.

Eduardo Zegarra: Nuestra gestión no paró ninguna de las obras heredadas de la gestión anterior, eso es falso. Hemos continuado y mejorado y hemos dado a Lima nuevos proyectos en transporte, Barrio Mío y la ampliación de las atenciones de salud. La ambición del partido de la señora no quiere esperar a las elecciones del año 2014 y ahora le costará a Lima la friolera de 250 millones de soles el próximo domingo. Si ellos se salen con la suya, nos obligarán a todos a ir en 8 meses otra vez a elecciones para volver a gastar 250 millones, es decir 500 millones. Y lo peor, la paralización y el caos que tendremos en Lima con 4 alcaldes en 2 años. Señora quisiera preguntarle otra vez ¿por qué no pueden esperar a las elecciones del 2014 para que su partido político pueda presentarse y competir por la alcaldía de Lima? ¿Por qué tanto apuro?

Federico Salazar: Muy bien, muchas gracias por esa respuesta. Nosotros tendríamos que pasar a la segunda pregunta sobre si se debe dejar el cargo de regidor, pero 
eso va a ser después de unos importantes mensajes. Volvemos inmediatamente. PAUSA COMERCIAL. Seguimos en voto informado ¿se debe revocar o no a las autoridades municipales? En este bloque se va a tratar de responder a la siguiente pregunta, adelante control.

\section{APARECE EN PANTALLA LA SEGUNDA PREGUNTA}

Federico Salazar: Bueno, como se ha dicho allí en la claqueta la pregunta es ¿se debe dejar el cargo de regidor, referido a la agrupación Confluencia Fuerza Social? Y tenemos ahora el turno de Patricia Juárez nuevamente con 3 minutos con 50 adelante.

Patricia Juárez: El pueblo de Lima quiere saber señores regidores de Fuerza Social si sus funciones son de dictar normas para la ciudad y fiscalizar la administración Municipal ¿por qué no han cumplido con su labor? El pueblo de Lima se pregunta ¿qué han hecho cuando el funcionario, señor Gustavo Guerra García Picasso y está probado en un video, mencionó que siguiendo instrucciones de la señora Villarán de la Puente acomodaría las bases del proceso de licitación de los corredores complementarios para que puedan ganar un grupo afín a la gestión? ¿Hay acaso alguna denuncia, comisión investigadora, se le sancionó, está denunciado penalmente? El pueblo de Lima quiere saber ¿qué acciones han tomado cuando se venció el contrato con LANSAC Línea Amarilla, dándole de manera directa la obra del parque Río Verde, burlándose sobre las normas de contratación pública que prohíbe adjudicar sin concurso público una obra por 80 millones de dólares? Por cierto a la empresa brasilera OAS, hecho que está denunciado en el Ministerio Público. El pueblo de Lima le pregunta a los regidores ¿qué denuncia, comisión investigadora formaron cuando el señor Miguel Prialé Ugaz suscribió el acta de acuerdo irrita, ilegal y sin un sustento técnico, que vició y desnaturalizó el contrato con LANSAC Línea Amarilla y sin tener facultad para ello? El pueblo de Lima pregunta a la señora Villarán y a los regidores

¿qué hicieron ante la grave denuncia contra el señor Manuel Prado cuando utilizó indebidamente recursos municipales para presentar los patrulleros maquillados, sin SOAT, placas, circulinas alquiladas y motos sin choferes? Fue un engaño decirle a la ciudad que la comisión de seguridad ciudadana se haría cargo de las investigaciones, cuando esta, sabemos todos, carece de esas funciones. Los vecinos de esta ciudad queremos saber ¿por qué la señora Villarán y los regidores no fiscalizan al SAT, quien exhibe triunfalmente 
logros inéditos en materia de recaudación, que se explican por algún inmobiliario porque se recauda impuesto de alcabala e impuesto vehicular, pero que sin embargo los niveles de eficiencia en recuperación han disminuido notablemente en la recaudación en el impuesto vehicular por falta de una adecuada gestión de cobranza? El pueblo de Lima quiere saber ¿qué han hecho la administración Villarán de la Puente para detener los enormes gastos que viene haciendo CERPAR, precisamente en este tiempo de campaña por la revocatoria, que solo en un caso asciende a un millón ochocientos mil, cuando este organismo no es autosostenible con los ingresos que percibe, es que se juega a gastar tan alegremente el dinero de todos los limeños? Le pregunto a la alcaldesa ¿con qué criterio seleccionó a sus regidores metropolitanos, que demuestran ser personas poco conocedoras de temas municipales? ¿Cómo explica la señora Villarán y sus regidores de Fuerza Social al país ese doble racero, de por un lado hacer antisistema, antiminero, bloquear 4 mil 800 millones de inversión privada en Cajamarca y señalar en Lima que son activistas y partidarios de la inversión privada brasileña? Como dice el periodista Phillip Butters isi el proyecto Conga contratará a las empresas brasileñas OAS y ODEBECH, Conga iba, porque si son coherentes ahí sí, a regidora Glave y su grupo antiminero estarían totalmente de acuerdo y no paralizarían Cajamarca? El pueblo le pregunta a la señora Villarán ¿por qué permite que el señor Zegarra, quien es regidor tenga asignada una camioneta, cuando el uso de los bienes municipales les está prohibido a los regidores y eso señor Zegarra, podría constituir peculado de uso? Por todo ello, la señora Villarán y sus regidores deben ser revocados, marcando 40 veces SÍ.

Federico Salazar: Muchas gracias, es el turno de Marisa Glave, representante de Confluencia Fuerza Social. Buenas noches, tiene un minuto con treinta.

Marisa Glave: Buenas noches Federico, buenas noches señora Juárez, buenas noches amigos y amigas que nos están viendo. El trabajo que hemos hecho estos años demuestra que nosotros contamos con mayor inversión privada para hacer más obras, tener más empleo y para lograr tener una mejor ciudad. Vía Parque Rímac es un gran ejemplo, ¿saben por qué? Porque renegociamos un contrato con la empresa que la gestión de la señora escogió. Y ¿qué cosa logramos? Logramos que además de la vía que existía originalmente, tuviésemos un viaducto para San Juan de Lurigancho, además un intercambio entre Ate y La Molina, además un gran parque en el medio de la ciudad. Y las 
familias que recibirían 5 mil dólares de compensación hoy recibirán 30 mil dólares de compensación. Inversión, empleo y mejora en la calidad de vida de la ciudad. Nuestra gestión, amigos ha logrado la mayor cantidad de inversión privada en la historia de Lima, lo hemos hecho con transparencia y lo hemos hecho con eficiencia. Mostrando siempre la verdad. Nosotros lograremos con esto crear 15 mil nuevos puestos de trabajo y ¿saben por qué? Porque creemos y queremos Lima, por eso quienes defienden la inversión en Lima apoyan a Susana Villarán y por eso quienes defienden a los trabajadores en Lima apoyan a Susana Villarán. Le pregunto a la señora ¿usted cree que 4 alcaldes en 2 años pueden facilitar la inversión privada en este país?

Federico Salazar: Muy bien, muchas gracias. Es el turno de Patricia Juárez, esta vez un minuto.

Patricia Juárez: Gracias. A los regidores les corresponde fiscalizar y no por cercanía amical o ideológica se pueden poner de costado. ¿Sabían que el presupuesto que ustedes aprobaron, destinaron el 40 por ciento de los recursos para inversión de los 2 años al proyecto Costa Verde y Playa Herradura, desconociendo proyectos más importantes como Escaleras, muros de contención? El pueblo se pregunta ¿por qué el concesionario de nuevas vías de Lima ODEBRECH invierte 585 millones de dólares y percibiría valor real por esa inversión una retribución aproximada de 1200 millones de dólares? Debemos responderle a los vecinos de Lima ¿si el compromiso de inversión y la ejecución de obras se hace con el recaudo del peaje, por qué antes de hacer un metro cuadrado de obra, ODEBRECH empieza a recaudar peaje para financiar las obras que no ha comenzado? El pueblo necesita una respuesta ¿si el peaje e incrementará por tramos y de 3 soles pasará a 4.50 cuando se produzca el 50 por ciento de avance de obras pasará a 6 soles?

Federico Salazar: Bien, si disculpe. Su turno ha terminado. Es el turno de Marisa Glave, esta vez tiene una exposición de 3 minutos con 50.

Marisa Glave: Esta noche quiero hablarle a las limeñas y a los limeños. Susana Villarán ha trabajado de manera incansable. Hemos realizado el mantenimiento vial de más de 300 kilómetros de vías de Lima Metropolitana. Eso quiere decir 20 veces la Javier Prado de pico a pico. Hemos, además, invertido en pistas en donde antes había arena en Huaycan y en San Juan de Lurigancho. Hemos recuperado plazas y parques. Hemos creado centros 
de recreación en Villa El Salvador, en Comas y en San Juan de Lurigancho. Hemos creado 4 nuevos hospitales, los hemos hecho nosotros, los pueden ir a ver en Villa María, el Rímac, San Juan de Lurigancho y en el Cercado de Lima. Además de invertir en infraestructura, Susana Villarán ha querido colocar al ser humano en el centro de la gestión y ¿qué cosa hemos hecho? Enfrentar la violencia contra la mujer, creamos Huarni Huasi para mujeres que sufren violencia y, además, las capacitamos para tener mejores herramientas económicas y salir adelante con sus niños. Atacamos también, la ausencia de oportunidades para los jóvenes. Tengo 31 años y sé qué cosa es salir y no saber si podrás estudiar, por eso creamos chicas y chicos chamba. Hoy 20 mil jóvenes de Lima Metropolitana reciben capacitación de la Municipalidad de Lima para tener oficios y tener empleo, y además, reciben asesoría psicológica porque es importante saber que tenemos un fututo. La salud nos importa mucho, como ya les dije hicimos 4 hospitales, 4 nuevos hospitales, pero además, en los ya existentes creamos nuevos programas, con quienes luchan contra el cáncer a la mama y contra el cáncer al cuello uterino, hemos creado cientos de despistajes gratuitos para las personas que más lo necesitan. Hemos, además, logrado que en nuestras farmacias los remedios sean mucho más baratos que en el resto de la ciudad. Pero sabemos que no es suficiente, sabemos que esperan más, por eso es que Susana Villarán y sus regidores hemos apoyado la inversión privada. Por eso es que hemos logrado 7 mil millones para poder invertir los recursos de la Municipalidad en infraestructura necesaria para los barrios. Hemos creado Barrio Mío, Barrio Mío va a tener muros, escaleras, pistas, veredas y parques en asentamientos humanos. Ya empezamos. Nosotros reconocemos que le gestión anterior invirtió 140 millones en 8 años y que lo que hicieron el algo importante y lo reconocemos. Pero en un año, solo en un año invertiremos el doble este año, pero el próximo año lo continuaremos. La gestión de Susana Villarán quiere resolver los problemas fe fondo de la ciudad y, por eso, busca una alianza con el gobierno nacional. Junto con el Ministerio de Vivienda empujaremos un programa de vivienda Municipal. Nosotros queremos generar soluciones que sean soluciones de fondo. El Programa Municipal de Vivienda Popular resolverá problemas de personas que viven en tugurios, resolverá problemas de personas de los asentamientos humanos y lograremos al final de la gestión 6 mil nuevos departamentos para limeñas y para limeños. Esto no puede parar, esto no puede parar por intenciones de quienes quieren volver a la Municipalidad y 
no pueden esperar al final del próximo año. Recuerde usted, le pido, reflexione ¿cuándo es el próximo proceso? Al final del próximo año ¿por qué no pueden esperar hasta ese momento, sabiendo que existen un conjunto de obras que nos van beneficiar a todos, a ustedes y a nosotros? Yo quiero realmente agradecerles por dejarme entrar en sus hogares, mirarlos directamente y decirles trabajamos con la verdad, trabajamos de la manera honesta, tenemos las manos limpias y tenemos el corazón grande y queremos esta ciudad.

Federico Salazar: Muchas gracias, es el turno de Patricia Juárez por un minuto con treinta segundos.

Patricia Juárez: Gracias. Espero que el pueblo que nos ve le crea a la señora Glave porque desgraciadamente los ciudadanos ya no podemos creer. Nos han engañado tantas veces y nos han dicho tantas mentiras que ya no soportamos más. Lima necesita una verdadera reconciliación, sin embargo, cuando a la señora Villarán de la Puente, forzada por las circunstancias, ha salido tardíamente a reconocer los errores de la gestión que reiteradamente hemos puesto en evidencia ha seguido siendo soberbia, he indicado que cogobernará con las fuerzas que la apoyaron en el NO. Otra vez desconoce e ignora a los millones de pobladores que acompañan el Sí y que forman parte de la comuna limeña que tiene una razón válida, justa, que perciben día a día el caos y desorden y una vez más hace responsable de esta revocatoria a ciudadanos que la han promovido, no es de un grupo político, no es de una persona, es del pueblo. ¿Es tan difícil entender que le pueblo ejercita su poder al poner y sacar a los gobernantes? Es por ello que nosotros, como muchos grupos acompañamos este sentimiento popular que nos hace decir basta de incapacidad, pongamos a Lima a marchar en paz, en armonía, con eficiencia, sin divisiones y por eso debemos marcar 40 veces SÍ. Para que nuestra querida y bendecida ciudad empiece un nuevo amanecer y que vuelvan las obras.

Federico Salazar: Muchas gracias, es el turno de Marisa Glave, representante de la Confluencia Fuerza Social. Un minuto.

Marisa Glave: A ustedes que nos escuchan, quiero volver a decirles hemos hecho obras y ustedes las pueden ver. Erramos en no comunicar, pero ahí están. Vayan y vean los 4 nuevos hospitales que están ahí, vayan y vean las nuevas vías, están ahí. Las obras existen y las hemos hecho. Hemos hecho mucho en este tiempo, pero también sabemos que 
necesitamos corregir cosas y nosotros, como lo ha dicho Susana de manera muy sincera y con el corazón en la mano, sabemos distinguir entre quienes promueven esto con intereses particulares y entre quienes tienen dudas. A los que tienen dudas, a los que nos han hecho críticas sinceras, las hemos escuchado, hemos corregido, hemos enmendado y con ustedes queremos seguir trabajando. Yo le pregunto y le vuelvo a preguntar ¿por qué señora Juárez si viene pronto, a final del próximo proceso electoral insisten, por intereses políticos, acelerar un proceso electoral?

Federico Salazar: Muy bien, muchas gracias, lamentablemente no hay opción a una respuesta a esas preguntas porque nos toca ya avanzar al siguiente bloque, pero por supuesto eso va a ser después de unos mensajes. Regresamos. PAUSA COMERCIAL. Muy bien, entramos al tercer bloque de acuerdo a lo que se firmó, la pregunta es ¿debe dejar el cargo de regidor en el caso del Partido Popular Cristiano? Y es el turno del señor Miguel Ángel Saldaña, representante del comité promotor que no está presente. Como los acuerdos son puntuales y personales, y se han firmado por ambas partes, lamentablemente no podemos reemplazar al señor Miguel Ángel Saldaña. Por eso vamos a tener que dejar correr el tiempo que se le había asignado, que son 3 minutos con 50.

\section{CORRE EL TIEMPO}

Federico Salazar: Muy bien corrido el tiempo, es el turno ahora del señor Pablo Secada Helguera, representante del Partido Popular Cristiano, tiene un minuto con treinta en esta parte. Buenas noches.

Pablo Secada: Buenas noches a todos, siempre es un placer debatir con Solidaridad Nacional. En la campaña del 2011 debatí con Elmer Cuba de MacroConsul, porque Solidaridad no tiene equipo económico. Hoy día debato con el hombre invisible y además mudo, porque como han oído solo prefiere el silencio. Quería responder primero a la causal de revocación, lo que dicen es que somos ineficientes y los regidores del PPC, como les consta a todos porque el consejo se discute públicamente, hemos fiscalizado a esta gestión continuamente. Hemos representado, por ejemplo, a las personas del mercado Mayorista, que hace poco salieron una microonda no 40 cualquier persona del mercado Mayorista, sino 40 de los líderes del mercado Mayorista con la regidora Olivia Cano que está sentada acá y con el regidor Óscar Ibáñez. Hemos propuesto desde la campaña del 
2010 con Lourdes, en el que hicimos una propuesta que fue entregada a esta gestión y está disponible para cualquiera que quiera revisar y hemos enriquecido esta propuesta en los últimos 2 años de experiencia en la gestión, en lo que se llama la Agenda para Lima. Entonces, si la causal de revocación en nuestro caso es ineficiencia, claramente la causal no opera. No hemos ido solamente a defender a nuestros regidores como algunos sostienen que es nuestra agenda encubierta, hemos ido más allá. Dejo eso para el siguiente bloque, después del minuto y medio de mi contrincante.

Federico Salazar: Muy bien, gracias señor Secada. Bueno el señor Miguel Ángel Saldaña tendría que responder por un minuto, vamos a dejar correr el tiempo.

\section{CORRE EL TIEMPO}

$37: 08$

Pablo Secada: ...claro, entonces sigo con el hilo que había pensado, que era ¿por qué el PPC ha puesto en su opinión en que 40 veces NO? ¿Por qué un partido que tiene 46 años de historia democrática, ha hecho algo que aparentemente no se entiende? ¿Por qué hemos ido contra la revocación? Bueno lo hemos hecho desde el 93. En el 94 votamos contra la ley, en el 2006 propusimos una ley para cambiar la derogación, porque como está debilita la democracia. Otra de las mentiras que se ha dicho es que esta revocación, en un país con instituciones débiles, con partidos débiles, fortalece a la democracia. Eso es claramente una mentira y está bien probado en la experiencia internacional y en la literatura. Además, este, volvimos a insistir votando contra la disminución de la baya en el 2009, cuando se pasa la mitad de electores a la mitad de votos válidos, eso acaba de pasar y es una diferencia inmensa, una diferencia de centenas de miles de votos de millones de votos. No sé si se han dado cuenta que en esta campaña han habido de mentiras, pero gruesas y falsas y medias verdades y desinformación. Una de las cosas que está pasando con esta revocación, es que esto es un negocio. El señor Marco Tulio Gutiérrez ha hecho un negocio de la revocación. Empezó hace un tiempo y sigue con un instituto que él mismo ha dicho que ha cobrado 70 mil soles por esta revocación. No sé si ustedes saben que vamos a pagar con nuestros impuestos, en el negado caso que el Sí gane la revocación, por la campaña del Sí. Eso es lo que está pasando, una de las cosas que está pasando que no quieren decir. Antes se mencionó que podríamos tener 4 alcaldes en año y medio, el 
número de los 250 millones de soles en los dos procesos y los 250 millones de soles adicionales los calculé yo, si quieren lo explico, es bien simple, la misma metodología que se utiliza en la segunda parte para calcular los beneficios para la ciudad, para hacer una carretera. Entonces, acá no hay ningún gato encerrado, es una cosa estándar, el Banco Central ha publicado recientemente la metodología, cualquiera la puede revisar y rehacer el cálculo si le parece. 250 millones de soles en costos para los contribuyentes y 250 millones de soles para los ciudadanos, los contribuyentes son los ciudadanos al final ¿cuánto invierte Lima en un año entero, cuánto es el presupuesto de inversión pública de Lima este año?

400 millones de soles, por favor que alguien me explique la lógica de gastar 500 millones de soles y quejarse de que no se hacen obras, cosa que como ya han oído es mentira, para gastar más de lo que se gasta en un año entero de gestión. La verdad es que yo no lo entiendo. Quisiera pasar a la tercera parte, pero iniciándola acá con un paraguas, el paraguas es la falta de decisión política, el paraguas es regresar a Lima para amedrar, el paraguas es no tomar decisiones porque no nos convienen y bajo ese paraguas podemos poner el túnel de San Juan de Lurigancho, la reforma de transporte o el no traslado del mercado de Santa Anita, que se quedó dos años vacío. Les sorprenderá lo del túnel de San Juan, bueno deberían saber que lo del túnel de Santa Rosa, el túnel de San Martín deberían estar separados 16 metros, y solo los separaron 7 metros 20. Y ¿por qué hicieron una cosa así de arriesgada? Para no expropiar, para no tomar el costo político y hacer las cosas como se deben hacer. Y ¿por qué está demorando rehacer el túnel? Porque se está haciendo bien.

72 millones de soles adicionales en encofrar todo el túnel, para que no se vuelva a caer. Ese es un ejemplo de las medias verdades o de las mentiras. Salgan un día de San Juan, en cualquiera de estos días y van a ver un inmenso cartel que dice 'la gestión de Lima cerró el túnel'. ¿Quién cerraría un túnel? El túnel se cayó y se está haciendo bien para que no se vuelva a caer cuando pasen por ahí los carros. A Dios gracias que se cayó cuando no había nadie adentro. Regreso después con los otros dos temas, mi contrincante tiene todavía un minuto y medio.

Federico Salazar: Efectivamente es el tiempo asignado y lo tenemos que respetar escrupulosamente porque se trata de un acuerdo formal de las partes. Sería entonces el turno de Miguel Ángel Saldaña que no se encuentra por un minuto con treinta.

\section{CORRE EL TIEMPO}


Federico Salazar: ...el tiempo asignado. La pregunta en cuestión es ¿debe dejar el cargo de regidor, en el caso de los regidores del Partido Popular Cristiano? Lamentablemente, el señor Miguel Ángel Saldaña no se ha hecho presente, de manera que pasado un minuto treinta es el turno de Pablo Secada por un minuto en esta parte final.

Pablo Secada: Nuestro país no puede seguir avanzando con instituciones precarias, con partidos políticos débiles. Están empezando a entrar a la política caras nuevas, hoy día han visto algunas y seguirán viendo en las próximas semanas caras nuevas. Gente que se ha jugado por el país, gente que tiene una voluntad de servicio probada, gente que viene con la mano limpia. Nosotros no solo no venimos a amedrar, sino que generalmente nos enfrentamos a los que amedran. Esto es solo un ejemplo más, hay una trayectoria de hacer eso que pueden constatar, hay una de las mentiras adicionales con la que quisiera terminar, y es una mentira pues, en el caso de un partido democrático como el PPC o en mi caso además, que dentro del PPC estoy en el lado más liberal del PPC, es una mentira que se cae de madura. Pero les pongo acá un cartelito que espero que las cámaras ponchen, este sería el alcalde de Lima si procede la revocación. Un comunista. Entonces, los que dicen que Lima podría enfrentarse al comunismo, que consideren bien que están haciendo, si votan por el SÍ, este es el alcalde del partido comunista peruano. Muchas gracias.

Federico Salazar: Gracias señor Secada, se ha terminado el tiempo de este bloque. Tenemos que ir a una pausa y vamos a regresar con la cuarta parte.

\section{PAUSA COMERCIAL}

Federico Salazar: Bien esta cuarta parte de Voto Informado, se va a responder a la pregunta ¿debe dejar el cargo de regidor, en el caso de los representantes de Restauración Nacional y Siempre Unidos? El reparto del tiempo es un tanto diferente, toca 3 minutos a cada uno. Y empezaría como representante del comité promotor de la revocación el señor Miguel Ángel Saldaña, pero él no se encuentra aquí. De manera que tendríamos que asignarle o darle el tiempo asignado, pero hemos consultado al propio presidente del Jurado Nacional de Elecciones y, bueno, se ha acordado aquí que se le é un tiempo simbólico para 
no afectar también al público televidente y al público aquí presente. De manera que vamos a dar 30 segundos de manera simbólica.

\section{CORRE EL TIEMPO}

\section{$44: 56$}

Federico Salazar: ... de Restauración Nacional tiene 3 minutos.

Iván Becerra: Buenas noches vecinos y vecinas de nuestra querida Lima. A la pregunta directa que se plantea, una respuesta directa, los regidores de la bancada Restauración Nacional no debemos dejar nuestros cargos de regidores porque no hemos incurrido en ninguna causal o hecho que amerite revocarnos. En todo caso, tampoco se nos ha imputado alguna causal individual por parte de los revocadores. En este sentido, debo manifestar que la revocatoria ha sido mal planteada, al incluirse en ella a todos los regidores de la oposición como nosotros, sin haber habido una evaluación, una crítica puntual, una causal puntual mostrada. Es decir, esta herramienta política de revocación no obedece al genuino interés social, sino obedece a intereses políticos individuales. Por el contrario, los regidores de la bancada Restauración Nacional, podemos afirmar que sí hemos cumplido con las funciones que la población nos ha encargado mediante su voto, hemos actuado con total honestidad dentro de las limitaciones inevitables de una bancada en minoría. Hemos hecho una oposición constructiva, apoyando las decisiones correctas y que benefician a Lima y nos hemos opuesto a las cosas que no creíamos correctas o que no estaban de acurdo a las normas jurídicas o a la Constitución o a nuestros principios morales que a nosotros nos gobiernan. Hemos apoyado decididamente a la aprobación de la ordenanza sobre la reforma integral del transporte público de Lima, además, hemos apoyado el Desarrollo Concertado de Lima 2012-2025 como el único instrumento de planificación para Lima. Hemos propuesto más de 11 ordenanzas que han sido aprobadas y están contribuyendo al bienestar ciudadano en temas de salud, transporte, vivienda, seguridad ciudadana, agricultura urbana y en favor del deporte. Están en trámite otras ordenanzas más como residuos sólidos y la protección de las playas del litoral de Lima. En suma, lo que estamos solicitando a la ciudadanía con todo respeto, es un voto justo de acuerdo a su valoración de la actuación de cada uno de los regidores. Por eso pido, los 
regidores de Restauración Nacional no hemos robado, no hemos mentido ni mucho menos somos incapaces pero sí hemos trabajado.

Federico Salazar: Bien, ha usado su tiempo. Todavía tiene alguno segundos más pero si usted quiere podemos pasar al siguiente si...

Iván Becerra: Finalmente, quiero dejar constancia, el representante del comité de revocación, encargado de revocarnos, de exponer los motivos porqué debe revocarnos a los regidores de Restauración Nacional, no se han presentado porque ellos han analizado que no existe motivo alguno o causa alguna para revocarnos.

Federico Salazar: Muy bien, muchas gracias entonces por haber hecho uso de la palabra señor Iván Becerra Hurtado. Tenemos ahora 3 minutos para el señor Luis Felipe Castillo Oliva, representante de Siempre Unidos.

Luis Castillo: Muy buenas noches vecino de Lima, te saluda Felipe Castillo, médico ginecoobstetra de profesión y regidor de Lima por el partido político Siempre Unidos. Yo estoy en contra del proceso de revocatoria por una cuestión de principio, porque es dañina y nefasta para la ciudad. Va a generar caos, incertidumbre en la ciudad y va a perjudicar a la ciudad que es el gobierno local más importante del país. Como lo he dicho, por una cuestión de principios yo estoy en contra del proceso de revocatoria, es dañina y nefasta para la ciudad. Y como lo he dicho, por una cuestión de principio no estoy...estoy en contra del proceso de revocatoria. Hemos contribuido con la gestión en obras de infraestructura vial importantes como Vía Parque Rímac, Vía Expresa Sur, en obras nuevas de Lima. Inversión privada por más de 1500 millones de dólares, que van conectar la ciudad con vías modernas y que junto a la reforma del transporte va a permit ir tener un transporte público de calidad, moderno, rápido, seguro, justo y digno. De tal forma que el vecino de Lima va a poder llegar más rápido a su casa, a su trabajo y va a gozar más tiempo con su familia. Con la misma actitud crítica y constructiva que hemos tenido en la gestión municipal, hemos contribuido con programas sociales como Barrio Mío, programa de Vivienda Municipal orientados a beneficiar a las poblaciones más vulnerables y con menos recursos económicos para que puedan tener más muros de contención, más agua, desagüe, más escaleras y poder beneficiarse también con más viviendas justas y dignas. Como médico y como miembro de la comisión de Medio Ambiente y Salud y Bienestar 
Social, hemos impulsado la ordenanza Marco que establece los mecanismos de prevención control y vigilancia de dengue en la provincia de Lima. De tal forma, que va a permitir desarrollar acciones para evitar la propagación del zancudo 'aedes aegypti', responsable de la transmisión del virus del dengue en la ciudad. Vecinos, por estas acciones creo que el Consejo Metropolitano no debe ser revocado, así que no a la revocatoria. Muchas gracias.

Federico Salazar: Muy bien, muchas gracias y, bueno, lo que tenemos a continuación...realmente lamentamos que no se haya expuesto los motivos en favor de la revocación de los regidores. Supongo que ya el comité promotor de la revocación tendrá otros medios para hacer conocer sus criterios. Pero en todo caso, acá no llegó el representante $\mathrm{y}$, por lo tanto, no hemos podido dar a conocer sus puntos de vista. Vamos ahora a unos mensajes y regresamos con la última parte del programa.

\section{PAUSA COMERCIAL}

Federico Salazar: Bueno, seguimos aquí en Voto Informado y estamos en este bloque, donde se dará pie a un mensaje final, supuestamente de parte del comité promotor y también de parte de los regidores. Sería el turno del doctor Luis Tudela Varela que no se encuentra, le toca un minuto con treinta, vamos a dar 30 segundos simbólicos para respetar ese tiempo, pero también no perjudicar a los televidentes y los aquí presentes.

\section{CORRE EL TIEMPO}

52:02

Federico Salazar: ... confluencia Fuerza Social, un minuto con treinta.

Marisa Glave: Este 17 de marzo, tenemos que tomar una decisión crucial para Lima. Yo defiendo el NO, para que Susana Villarán y todos los regidores del Consejo se queden en la Municipalidad de Lima. Y les he explicado cuales son nuestras razones para decir no, pero sé que muchos de ustedes tienen dudas. Sé que hemos cometido errores y los hemos remendado. Hemos escuchado las críticas para poder hacer de esta una mejor gestión. Yo les pido que pensemos un poco, qué cosa es lo que pasaría si es que finalmente ganara la otra opción. Estaríamos 8 meses parados esperando elecciones, 8 meses con

suplentes que lo único que harían es esperar una nueva elección. En esa elección escogeríamos a un nuevo alcalde y a un nuevo Consejo, solamente por un año ¿y luego que 
vendría? Una nueva elección. Todo ese tiempo y todo ese dinero ¿qué pasaría con las obras? ¿Qué pasaría con Barrio Mío y los muros de contención? ¿Qué pasaría con la reforma del transporte, tan vital en esta ciudad? ¿Qué pasaría con el programa municipal de Vivienda Popular? Todo suspendido, todo parado ¿merecemos esto? ¿Merece eso Lima? Les pido que reflexionemos, que pensemos, que nos cojamos el corazón y pensemos qué es realmente lo mejor para Lima. Yo los invito, amigas y amigos, este 17 marcar 40 veces no.

Federico Salazar: Muy bien, muchas gracias. Es ahora el turno del señor Luis Felipe Calvimontes Barrón, representa al Partido Popular Cristiano, un minuto con treinta.

Luis Calvimontes: Buenas noches ciudadanos de Lima. Hemos escuchado los argumentos de quienes nada proponen. Hemos escuchado los argumentos de quienes nos quieren llevar a un salto al vacío, es decir, de quienes proponen sumas que definitivamente restan. Pero además, no hemos podido escucharlos y lamentamos profundamente que quienes proponen la revocatoria no se hayan presentado a poder debatir y a poder expresar sus ideas. Los regidores del Partido Popular Cristiano somos una nueva generación, que gracias a la generosidad de su voto estamos en el Consejo Municipal. Constituimos una fuerza de oposición constructiva y democrática que propone ideas claras, hacer que se completen obras, garantizar que se trabaje más y hacer que esta gestión no cometa errores. Vecinos, les planteo un momento de reflexión importante, el próximo año hay elecciones municipales y regionales en todo el país, pase lo que pase con este proceso de revocatoria. Exponer a los limeños a tener desde las próximas semanas un alcalde provisional por 6 meses u 8 meses que nada podrá hacer y de inmediato entrar a una nueva campaña municipal, solo llevará a Lima a un problema muy serio. Un alcalde complementario que solo gobernará hasta las elecciones del 2014, el próximo año. Por eso, como regidor de Lima, como opositor a la actual gestión municipal, como vecino y como demócrata les pido reflexión y grandeza sobre su voto. Está en sus manos que eso no ocurra. Por eso, este 17 de marzo les pedimos marcar 40 veces no. Muchas gracias.

Federico Salazar: Bien gracias, su tiempo está vencido. El señor Iván Becerra Hurtado, representante de Restauración Nacional, tiene 1 minuto con treinta.

Iván Becerra: En primer lugar, agradecemos a Dios por habernos dado el privilegio de servir al pueblo de Lima como regidores metropolitanos. A nuestro partido 
político Restauración Nacional y a su pastor Humberto Lay, por habernos dado la oportunidad así como su respaldo. Personalmente agradezco a mi esposa Zulema, a mis hijos Sebastián y Nicolás por su permanente apoyo y aliento. $\mathrm{Y}$ a los vecinos y vecinas de nuestra querida Lima, estamos seguros este domingo evaluaran de forma justa y consiente nuestra labor como regidores. A ustedes les decimos con humildad y con sinceridad, que con las imperfecciones de todo ser humano, hemos cumplido con la responsabilidad que nos han encomendado como regidores representando al partido político Restauración Nacional. Por ello, apelando a su generosidad, nos atrevemos a pedirles amigas y amigos, hermanas y hermanos, residentes de Lima y a todos los paisanos andinos que este próximo domingo nos apoyen marcando el recuadro del NO número 36 y 37, y asimismo, no a la revocatoria. Hermanos y amigos acudan a las urnas a emitir su voto con responsabilidad y de acuerdo a su conciencia, pero siempre pensando primero en Lima y no en intereses particulares. Gracias y que Dios les bendiga.

Federico Salazar: Muy bien, muchas gracias. Es el turno de Luis Felipe Castillo Oliva, representante de Siempre Unidos, un minuto con treinta.

Luis Castillo: Vecinos de Lima, amigos, simpatizantes y militantes del partido político Siempre Unidos, no debo ser revocado porque creo que he cumplido honestamente el encargo que la ciudad de Lima me dio cuando me eligió regidor de la minoría y desde la oposición hemos contribuido con una actitud crítica y constructiva en el fortalecimiento de la gestión municipal. De tal forma, que los vecinos han tenido mejores condiciones de vida, sobre todo los vecinos de la Lima emergente, de la Lima provinciana a la cual yo represento. El Consejo Metropolitano no debe ser revocado porque si se revoca va a haber caos, incertidumbre en la ciudad, va a generar más gastos económicos al Estado porque habrá que elegir una nueva autoridad por un periodo corto de tiempo, es decir, más pérdida de tiempo. Además, tendríamos 4 alcaldes en un periodo de 18 meses, con visiones distintas de gestión municipal, en consecuencia, paralización de obras y reformas importantes que tanto necesita el vecino, en perjuicio del desarrollo de la ciudad. Vecinos, por estas razones recurro a los más sensible y sublime de tus sentimientos, para que reflexiones y nos apoyes este 17 de marzo un voto de conciencia marcando 40 veces no por la gobernabilidad de Lima, tu ciudad. Muchas gracias. 
Federico Salazar: Muy bien, muchas gracias. Gracias a todos por haber expuesto sus motivos y haber hecho esta locución final. Tenemos que hacer ahora una pausa y regresamos con lo último de Voto Informado.

\section{PAUSA COMERCIAL}

\section{$58: 27$}

Federico Salazar: ... la última parte de Voto Informado con un mensaje final, con respecto al cargo de la alcaldesa de Lima Susana Villarán. Tenemos ahí una plaqueta, adelante control.

Federico Salazar: Bueno, sería el turno de acuerdo a lo acordado de la señora Patricia Juárez Gallegos como representante del comité promotor de la revocación, lamentablemente ella ha abandonado el local y, bueno, le tocaban 3 minutos. De manera que, vamos a otorgar 30 segundos de manera simbólica, adelante.

\section{CORRE EL TIEMPO}

59:33

Federico Salazar: ... el tiempo. Es el turno del señor Eduardo Zegarra como representante de la alcaldesa. Un mensaje final de 3 minutos.

Eduardo Zegarra: Queridos vecinos y vecinas de Lima, déjenme en primer lugar pedir disculpas por lo que hemos visto hoy día. Lo que hemos visto hoy día ha sido una falta de respeto a toda nuestra ciudad que esperaba escuchar motivos para pretender revocar nada menos que a la alcaldesa y todo el Consejo Metropolitano. Hoy día venimos a exponer, venimos a decir nuestra verdad y lo único que hemos encontrado es que se han corrido del debate como lo han venido haciendo desde el inicio de esta campaña. No han querido debatir, hoy día vinieron un rato y luego se fueron. Yo creo que tengo que aclarar 2 cosas que ha dicho la señora Juárez que en realidad son mentiras. Ella ha dicho que nosotros hemos paralizado el túnel Santa Rosa de San Juan de Lurigancho, el túnel lo construyó el señor Castañeda y se derrumbó. Ese túnel iba a dejar que muchos miles de personas de San Juan de Lurigancho se transportaran por allí. Tuvimos que hacer un nuevo proyecto y tuvimos que invertir 70 millones de soles para que nunca más vuelva a ocurrir un derrumbe de esta naturaleza. Eso ha llevado un tiempo, pero ahora el túnel estará listo el 
próximo año. Nosotros no paralizamos nada, se derrumbó porque se hizo mal. Y quiero decirle también, que no es cierto que haya algo raro, algo malo en los peajes, eso estaba contractualmente hecho por la gestión de su jefe y nosotros hemos tenido que respetar los contratos hechos y eso respetamos y por eso es que la inversión privada cree en nuestra gestión. Quiero decirles y quiero dirigirme ante todo, a aquellos que tienen dudas sobre qué es esto de la revocatoria. Están diciendo, la verdad que no entiendo, algunos incluso piensan que votar por el SÍ es para que Susana se quede. Quiero decirles que el voto para Susana es el voto por el NO, para que nos quedemos y podamos seguir trabajando por Lima. No hay mal que por bien no venga, esta revocatoria nos ha demostrado que podemos unirnos. Nuestra alcaldesa y nosotros sabemos que no es fácil gobernar Lima, una sola fuerza política no lo puede hacer, por eso es que Susana esta semana ha convocado a otras fuerzas políticas, a otros líderes. Hoy día Lourdes Flores ha aceptado esa convocatoria, ha aceptado la posibilidad de hacer un gobierno de ancha base, que le dé a Lima mayores perspectivas en los próximos 2 años. Creo que ese es un mensaje fundamental, hemos visto que otros líderes como Pedro Pablo Kuczinsky, Alejandro Toledo, Javier Pérez de Cuéllar le han dado el apoyo al NO y porque quieren y creen que Lima debe seguir y no debe parar. Quiero terminar diciéndoles que este 17 de marzo, 40 veces $\mathrm{NO}$ es la forma de darle a Lima u futuro que todos merecemos. 40 veces NO es la Lima que soñamos, la Lima para todos que estamos construyendo. Muchas gracias y buenas noches.

Federico Salazar: Muchas gracias señor Zegarra. Lamentablemente co hemos contado con la mayor parte de los miembros del comité promotor de la revocación para que expongan sus motivos. Acá tengo el acta del pacto ético electoral. Uno de sus puntos dice que el fin de esta acta es exponer públicamente y mediante debates hacia los ciudadanos los motivos e ideas que fundamenten la solicitud de revocatoria por parte de los promotores y los argumentos por parte de las autoridades municipales con el fi que el ciudadano conozca y compare oportunamente y pueda emitir un voto informado y consiente. Obviamente, un debate como este se tiene que organizar con reglas formales y reconocidas y en cumplimiento de esas reglas, de esos acuerdos explícitamente firmados por cada una de las partes, es que no hemos admitido que haya un reemplazo de los representantes de la opción del comité promotor de la revocación. Realmente nos da mucha pena, pero tenemos todavía una semana para que las partes expongan sus motivos y los ciudadanos puedan emitir el 
proximo domingo un voto realmente informado. Muchisimas gracias a todos y muy buenas noches y mucha suerte el proximo domingo.

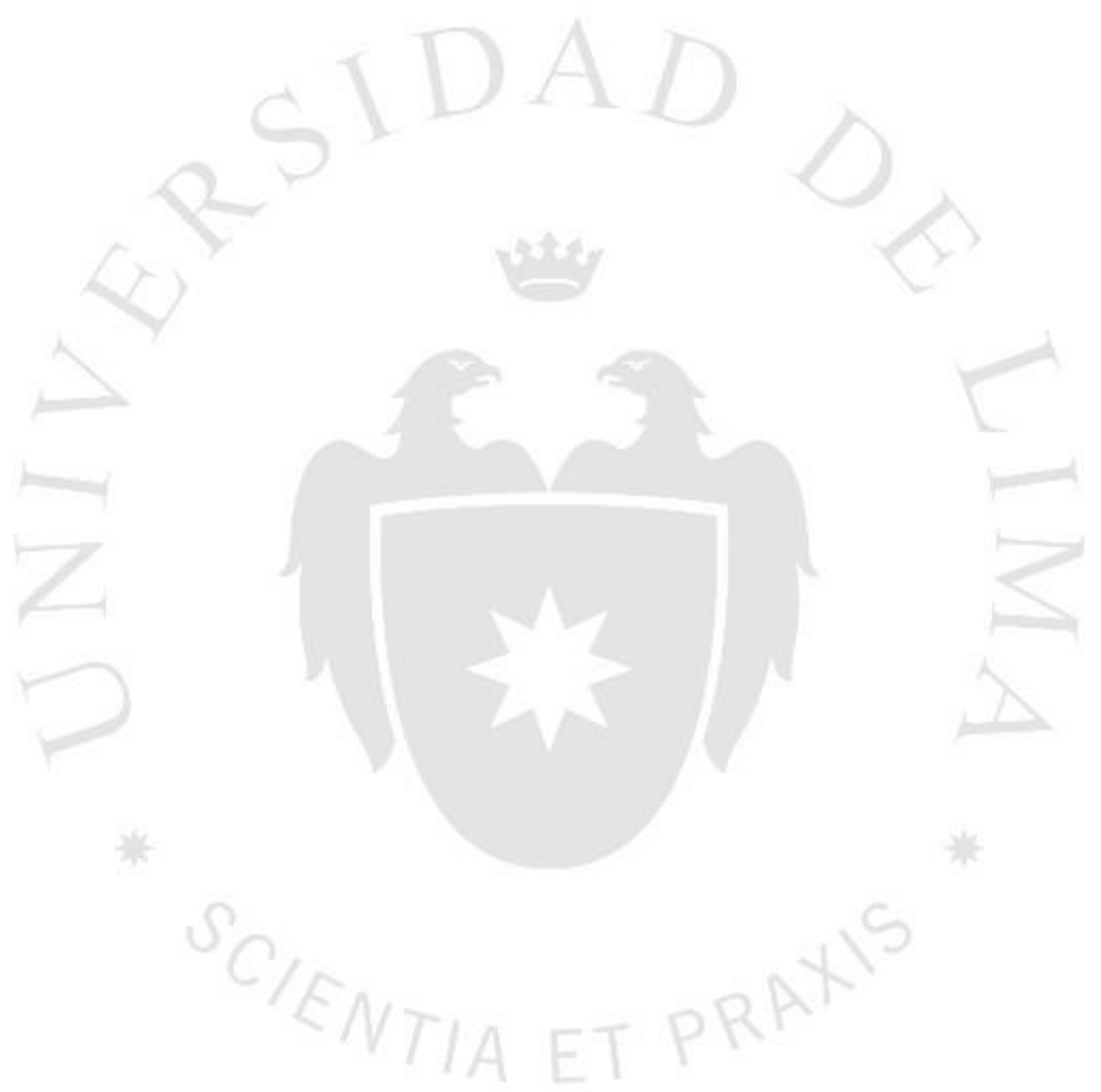

